\title{
New species of Dilobitarsus Latreille with tetra-tuberculated pronotum (Coleoptera, Elateridae, Agrypninae)
}

\author{
Sônia A. Casari ${ }^{1}$ \\ ${ }^{1}$ Museu de Zoologia, Universidade de São Paulo. Caixa Postal 42494, 04218-970 São Paulo-SP, Brasil. casari@usp.br
}

\begin{abstract}
New species of Dilobitarsus Latreille with tetra-tuberculated pronotum (Coleoptera, Elateridae, Agrypninae). Four species of Dilobitarsus Latreille, 1834, D. angulosus sp. nov. (Brazil: São Paulo, Rio de Janeiro), D. bellus sp. nov. (Peru), D. nigrus sp. nov. (Argentina) and D. thoraconstrictus sp. nov. (Bolivia) are described, and D. quadrituberculatus Candèze, 1857 is redescribed. Diagnostic characters of all studied species are illustrated and new records for D. quadrituberculatus are included. A key to Dilobitarsus species from the Neotropical Region is also presented.

KEYWORDS. Agrypnini; genitalia; Insecta; new records; mouthparts; South America.
\end{abstract}

Dilobitarsus was erected by Latreille (1834) to include Elater bidens Fabricius, 1801 from Brazil and "NouvelleGrenade". Another species from Brazil, D. petiginosus, was described by Germar (1840). Candèze (1857) redescribed the genus and stated that Dilobitarsus is very similar to Adelocera Latreille, 1829 but, the species of both genera are easily separated especially by the lamellate tarsomeres in the former. According to him, species of Dilobitarsus are recorded from South America and probably they live inside dead trunks of trees. He described eight species and redescribed the two already known. Also he presented a key for 10 species including three with four tubercles on the pronotum: D. colombianus with tubercles weak and $D$. lignarius and $D$. quadrituberculatus with tubercles well developed. In 1874, Candèze described other six species. After this, fourteen species were described individually by different authors. The last one was described by Golbach (1983).

Von Hayek (1973) studying the tribe Agrypnini presented a generic diagnosis to Dilobitarsus and stated about the typematerial and new combination of 23 species of this genus. Golbach (1983) described one species from Paraguay and presented a key to species recorded from Central and South America, totalizing 24 species. The synopsis of the key resulted in a diagram representing the relationships among the species, and the genus is divided in two groups: one formed by species with protuberances on pronotum (14 species) and other without protuberances (10 species). The four species with a tetra-tuberculated pronotum form a sub-group of the first group.

After Golbach (1983) no additional species has been included and the genus Dilobitarsus is now composed by 24 species distributed from North (Mexico), Central and South America, and one species (D. pendleburyi Fleutiaux) recorded from Borneo. Five described species have four tubercles on the pronotum: D. cariosus Candèze, 1889 (Colombia), D. colombianus Candèze, 1857 (Colombia, Argentina), D. lignarius Candèze, 1857 (Argentina, Brazil, Uruguay, Paraguay), D. pendleburyi Fleutiaux, 1934 (Borneo) and D. quadrituberculatus Candèze, 1857 (Brazil, Peru). Dilobitarsus pendleburyi is the only species recorded from Asia and it is not included in this work because it needs confirmation if it is congeneric with the other species.

All species included in this genus are known only from their original descriptions (Fabricius 1801; Germar 1840; Solier 1851; Candèze 1857, 1874, 1889, 1897; Fairmaire \& Germain 1860; Philippi \& Philippi 1860; Schwarz 1902; Fleutiaux 1907, 1934; Golbach 1983). The paper of von Hayek (1973) is of valuable importance, presenting the synonymies, new combinations, list of type material and distribution of the members of Agrypnini including all known species of Dilobitarsus. Their morphology has been little studied and the male and the female genitalia are unknown for this genus.

Here, four species, D. angulosus sp. nov., D. bellus sp. nov., D. nigrus sp. nov. and $D$. thoraconstrictus sp. nov., are described and illustrated. Dilobitarsus quadrituberculatus, with new records, is redescribed and illustrated in order to better compare it with the species with tetra-tuberculated pronotum. A key for the New World species is also included.

\section{MATERIAL}

The material studied is deposited in the following institutions: American Museum of Natural History, New York, New York (AMNH); Departamento de Zoologia, Universidade Federal do Paraná, Curitiba, Paraná (DZUP); Museo Noel Kempff Mercado, Santa Cruz de la Sierra (MNKM); Museu de Ciências Naturais, Porto Alegre, Rio Grande do Sul (MCNZ); Museu Nacional da Universidade Federal do Rio de Janeiro, Rio de Janeiro, Rio de Janeiro (MNRJ); Museu de Zoologia da Universidade de São Paulo, São Paulo, São Paulo (MZSP). 
The material of Dilobitarsus thoraconstrictus $\mathbf{s p . ~ n o v . ~ w a s ~}$ received from James Wappes, American Coleoptera Museum, San Antonio, Texas (ACMT), for identification. Following the Bolivian laws, the holotype of this species was deposited in MNKM.

\section{TAXONOMY}

\section{Dilobitarsus angulosus sp. nov.}

(Figs. 1-13, 73-76)

Description. Body length: $21 \mathrm{~mm}$ (holotype); $18 \mathrm{~mm}$ (paratype). Integument entirely reddish-brown, including legs and antennae. Pubescence yellow dorsally and ventrally; distal half of elytra with dark-brown pubescence on entire surface or dark-brown with yellow patches (Figs. 73-76).

Frons (Figs. 2, 73) wider at base; grooved longitudinal medially on basal half; strongly concave between fore angles; strongly declivous on anterior half; fore angles rounded, carinate and raised; anterior margin straight, surpassing fore angles; punctation coarse and dense. Antenna (Figs. 1, 73, 74) longer than pronotosternal groove; serrate; $3^{\text {rd }}$ antennomere slightly shorter than $4^{\text {th }}$ and with same shape.

Pronotum (Figs. 2, 3, 73-76) longer than wide, narrowed anteriorly; lateral margins almost straight excluding fore and hind angles; fore angles wide and rounded; anterior margin almost straight and raised on median two-quarters; moderately convex, declivous on basal third; grooved near lateral margins, at base of hind angles and longitudinal medially; two pairs of rounded tubercles very near each other on anterior half of median third; basal pair larger than anterior; hind angles very prominent, triangular and divergent, weakly carinate; apices surpassing lateral margins of elytral base; median basal tubercle well developed, elongate, with posterior margin rounded; punctation coarse and dense. Hypomera concave; raised at border of pronotosternal groove; grooved longitudinal medially, parallel pronotosternal groove; smooth and strongly grooved near posterior margin (to accommodate profemur); punctation coarse and dense. Pronotosternal groove almost reaching procoxal cavity. Prosternum convex, flattened between procoxae; punctation coarse and sparse, denser near pronotosternal groove. Prosternal lobe prominent and rounded; anterior margin slightly emarginate and downwardly directed; punctation very coarse and sparse, similar that of prosternum. Prosternal spine (Fig. 4) with apex acute and curved, and subapical lobe rounded. Mesosternal cavity (Figs. 4, 5) narrow, V-shaped with borders wide and almost horizontal on anterior half and slightly declivous on basal half. Mesepisternum and metasternum concave near mesocoxa (to accommodate mesofemur). Metasternum (Fig. 5) narrow between mesocoxae, almost with same width than mesosternal cavity base; metathoracic discrimen wellmarked; punctation coarse and dense. Metacoxal plate (Fig. 6) with wide rounded lobe and strongly narrowed laterally. Apex of tibia with row of spiniform setae. Tarsomeres 1-4 lamellate beneath; lamella of tarsomere 1 very short; lamella of tarsomere 4 well visible and shorter than tarsomere. Claws with one long basal seta; seta almost as long as claw. Scutellum elongate, pentagonal and declivous.

Elytra (Figs. 73-76) convex, flattened longitudinal medially; strongly declivous anteriad in an area slightly longer than scutellum; punctate-striate; striae marked by row of coarse punctures; interstices flat and punctate except $4^{\text {th }}$ forming a weak ridge on median third; apices narrow and conjointly rounded; each elytron at base with two concavities, one near scutellum and other near lateral margin, forming an elongate tubercle at middle and other at fore angle.

Tergite VIII (Fig. 7) slightly wider than long, slightly narrowed apicad, translucent median basally; covered by short setae on distal two-thirds; setae longer and more concentrate near margins. Sternite VIII (Fig. 8) wider than long (considering only sclerotized area), widened at basal third and narrowed on distal two-thirds; densely setose except base laterally; spiculum gastrale two times longer than sternite. Ovipositor (Figs. 11-13) with one-segmented stylus with one long seta and several microsetae at apex. Bursa copulatrix (Figs. 9, 10) with band-like sclerotized piece, microspined at base and with long teeth internally; sclerotized toothed band long, almost reaching middle of bursa copulatrix.

Type material. Holotype female. S[erra] [da] Bocaina 1650m, S[ão] J[osé][do] Barreiro, SP [São Paulo] Brasil XI.1968, Alvarenga e Seabra; Coleção M. Alvarenga (DZUP). Paratype female. [Brazil: Rio de Janeiro] Itatiaia (MNRJ).

Etymology. The specific epithet is a derivative of the Latin word angulosus (= prominent) referring to the shape of hind angles of pronotum.

Remarks. The yellow pubescence of paratype is paler than that of holotype; on distal half of elytra the pubescence is totally dark-brown on holotype and dark-brown with yellow patches on paratype.

Dilobitarsus angulosus sp. nov. is similar to D. bellus $\mathbf{s p .}$ nov. in pubescence coloration, but both species are easily separated especially by (condition in D. bellus sp. nov. parenthesized): antennae reddish-brown (brown); elytral integument unicolor (bicolor); prothorax, including hind angles, wider than elytral base (narrower than elytral base); lateral margins of pronotum excluding fore and hind angles almost straight (slightly sinuous); pronotum with longitudinal median groove and tubercles with rounded apex (pronotum without longitudinal median groove and tubercles with rounded apex and located on a higher platform); posterior pair of tubercles larger than anterior (anterior pair of tubercles larger than posterior); hind angles of pronotum prominent laterally and weakly carinate (hind angles of pronotum not prominent, only narrowed at base, and not carinate); metasternum narrow, as wide as base of mesosternal cavity (metasternum wide, wider than base of mesosternal cavity, and flattened behind mesosternal cavity); metacoxal plate with wide rounded lobe (wide and short lobe, almost straight); metathoracic discrimen well-marked (weak); lamella of tarsomere 4 shorter than tarsomere (longer than tarsomere). 

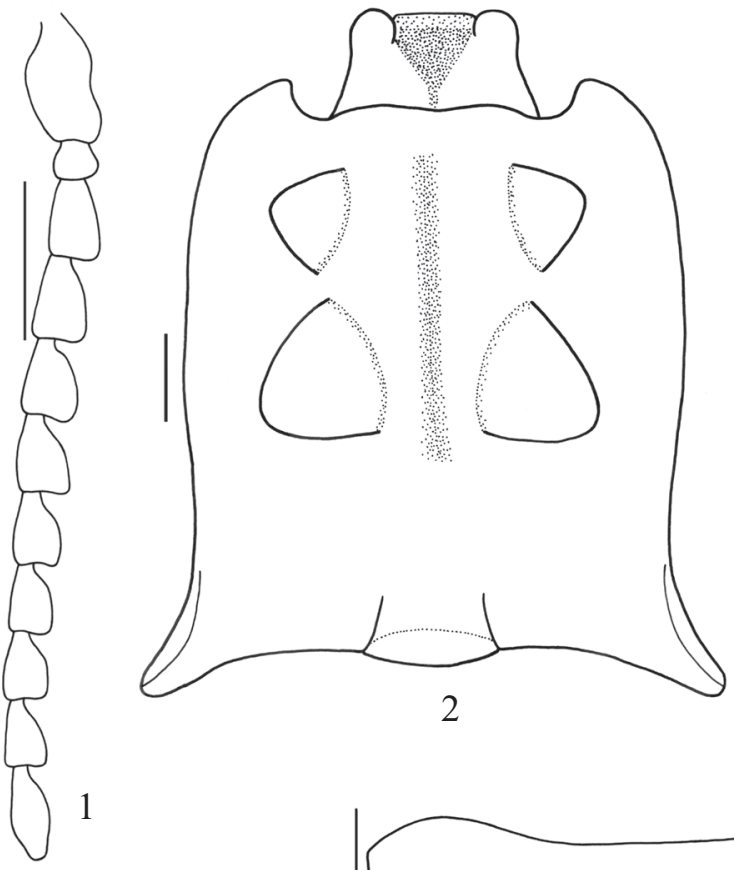

2

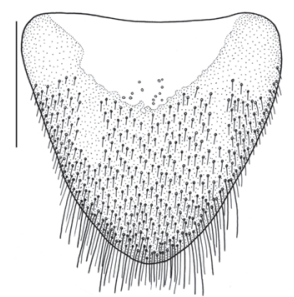

7
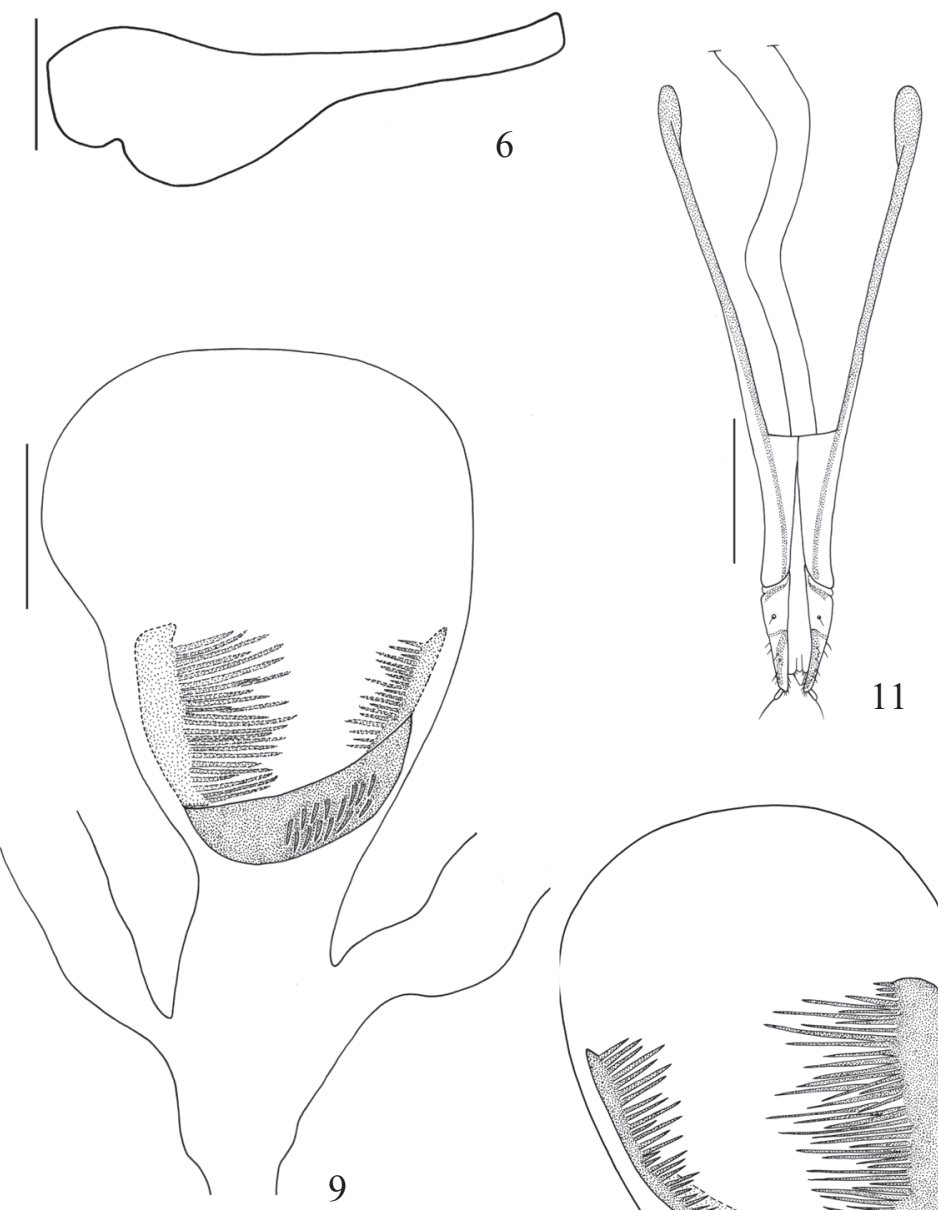

3

1
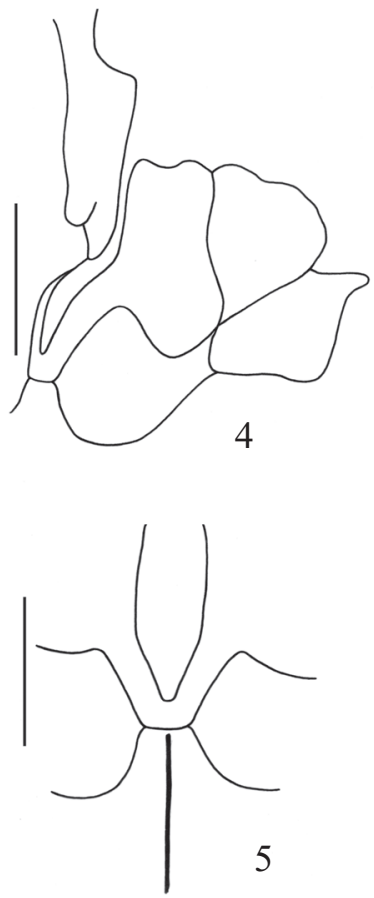

Figs. 1-13. Dilobitarsus angulosus sp. nov. Female: 1, antenna; 2, frons and pronotum; 3, prothorax (lateral); 4, prosternal spine and mesothorax (lateral); 5, mesosternal cavity and median anterior region of metasternum; 6, metacoxal plate; 7, tergite VIII; 8, sternite VIII; 9, 10, bursa copulatrix (dorsal, ventral); 11, ovipositor and baculi (dorsal); 12, 13, ovipositor (ventral, dorsal). Bars $=1 \mathrm{~mm}$. 


\section{Dilobitarsus bellus sp. nov.}

(Figs. 14-24, 77, 78)

Description. Body length: $18 \mathrm{~mm}$. Integument ferrugineous; distal third of elytra black; antennae brown except two first antennomeres. Pubescence: dorsally golden-yellow, denser on pronotum; distal third of elytra with pubescence black with patches of denser golden-yellow setae (Figs. 77, 78); yellowish ventrally (including legs), except for golden-yellow prothorax and tarsi.

Frons (Figs.15, 77, 78) narrow, grooved longitudinal medially on basal half; concave anteriorly, between fore angles; fore angles prominent and rounded; anterior margin straight and prominent, longer than fore angles, covering labrum partially; punctation coarse and dense. Antenna (Figs. $14,78)$ longer than pronotosternal groove; serrate; $3^{\text {rd }}$ antennomere triangular-elongate, longer than $4^{\text {th }}$.

Pronotum (Figs. 15, 16, 77, 78) longer than wide, narrowed at hind angles base and frontally; lateral margins slightly sinuous; fore angles prominent, narrowed and rounded; strongly convex on anterior half; concave and declivous on basal half; grooved at base of hind angles; two pairs of rounded and moderately developed tubercles, disposed very separate, near base of anterior half; anterior pair larger than posterior; hind angles wide, narrowed at base and not carinate; punctation coarse and dense. Hypomera flat, concave anteriorly; smooth and concave near posterior margin (to accommodate profemur); punctation coarse and dense. Pronotosternal groove almost reaching procoxal cavity. Prosternum convex, flattened between procoxae; punctation very coarse and sparse. Prosternal spine with acute apex and subapical lobe rounded. Prosternal lobe prominent; anterior margin strongly emarginate at middle and backwardly directed; punctation very coarse and sparse. Mesepisternum and metasternum concave (to accommodate mesofemur). Mesosternal cavity (Fig. 17) with borders V-shaped, wide and horizontal on basal half and slightly declivous on anterior half; metathoracic discrimen weak. Metasternum wide and flattened behind mesosternal cavity, wider than base of mesosternal cavity; punctation moderately coarse and dense. Metacoxal plate (Fig. 18) with wide and slightly rounded lobe, strongly narrowed on lateral half. Tarsomeres 2-4 slightly dilated and with lamella beneath; membrane increasing in size toward apex; lamella of tarsomere 4 longer than tarsomere. Claws with one long basal seta.

Elytra (Figs. 77, 78) strongly narrowed on distal third; convex, declivous anteriorly near scutellum; punctation coarse and dense; apex narrow and conjointly rounded; striae not completely well-defined, well visible on distal half.

Tergite VIII (Fig. 21) slightly wider than long, slightly narrowed apicad; translucent at base; distal margin wide and rounded; setae on distal two-thirds (not represented in Fig. 21), longer near margins. Sternite VIII (Fig. 22) transverse, band-like, strongly narrowed on distal half; distal margin moderately deep and widely emarginate forming two rounded lobes; translucent with one longitudinal sclerotized band on each side, starting on anterior lobe and not reaching basal margin; setae near lateral margins and on longitudinal band starting on distal lobes and not reaching basal margin. Tergite IX (Fig. 19) transverse, slightly narrowed apicad; distal margin slightly deep and widely emarginate; emargination about one-fifth of tergite length; a few very short setae near each lateral margin. Tergite X elongate with apex rounded; microspined laterally. Sternite IX (Fig. 20) elongate, strongly widened at middle making lateral margins strongly sinuous; slightly narrow near apex; distal margin wide and rounded; setae on distal third. Aedeagus (Figs. 23, 24): parameres separate ventrally, 1.4 times longer than median lobe; apex slightly narrowed and cuneiform; subapical tooth slightly acute; setae denser ventrally; median lobe narrow, slightly narrowed apicad, with constricted apex; basal struts surpassing basal margin of parameres dorsally and not reaching base ventrally.

Type material. Holotype male. Peru (AMNH).

Etymology. The specific epithet is a derivative of the Latin word bellus (= cute, pretty) referring to the shape of the body.

Remarks. The integument coloration of D. bellus sp. nov. is similar that of $D$. thoraconstrictus sp. nov., but the pubescence coloration is brighter and the pronotum is sligthly narrower than the base of elytra in the former and strongly narrower in the latter. Besides, the anterior pair of tubercles is larger than the posterior pair in the former and smaller in the latter. A comparison with $D$. angulosus sp. nov. is presented above.

\section{Dilobitarsus nigrus sp. nov.}

(Figs. 25-35, 79, 80)

Description. Body length: $16 \mathrm{~mm}$. Integument black. General dorsal pubescence golden-yellow and black; frons with setae black on anterior half and golden-yellow on basal half; pronotum covered by golden-yellow setae, brighter and denser; scutellum with black and sparse setae; elytra with pubescence black and sparse with yellowish setae on lateral margins and irregular patches (Figs. 79, 80); pubescence ventrally finer and black with very sparse whitish setae intermingled among black; ventrites with one patch of yellowish stouter setae each side.

Frons (Figs. 26, 79, 80) grooved longitudinal medially on basal half; concave anteriorly, between fore angles; fore angles prominent and rounded; anterior margin straight and prominent, longer than fore angles, covering labrum partially; punctation coarse and dense. Antenna (Fig. 25) short, as long as pronotosternal groove; serrate; $3^{\text {rd }}$ antennomere as long as $4^{\text {th }}$; antennomeres 3-11 rounded laterally.

Pronotum (Figs. 26, 27, 79, 80) slightly longer than wide, slightly wider than base of elytra; almost rectangular; fore angles wide and rounded; anterior margin prominent and raised at median third; lateral margins almost straight, slightly sinuous near fore angles; hind angles wide, slightly divergent, emarginate laterally, carinate at middle; strongly 


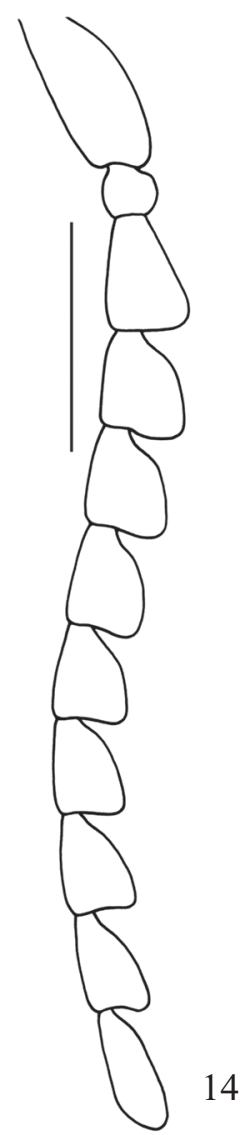

14

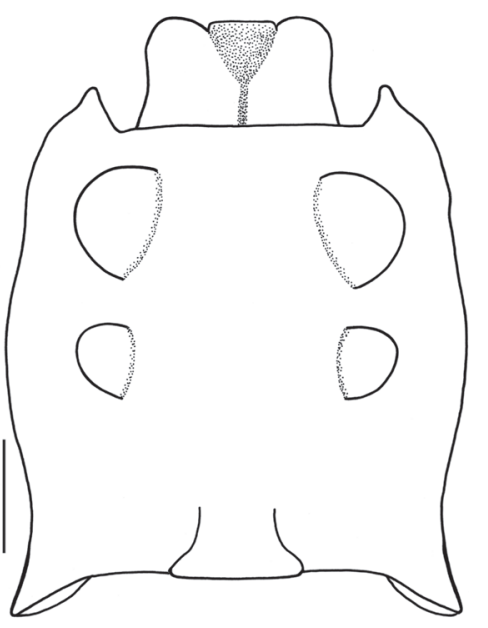

15

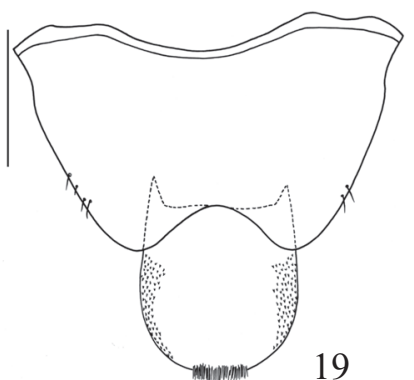

19
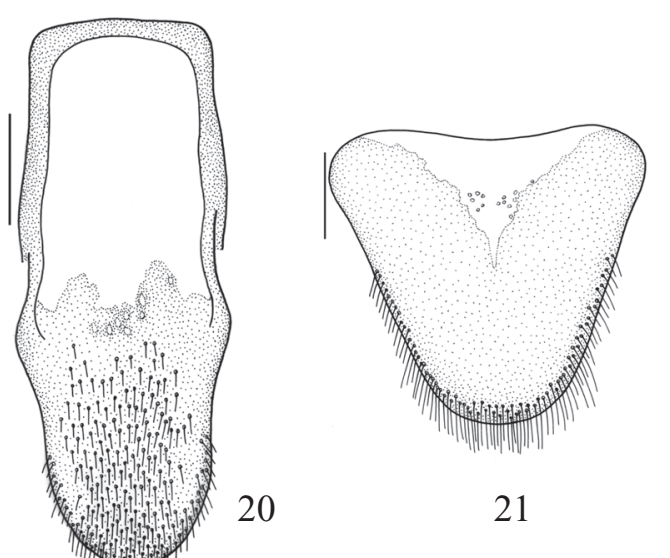

21
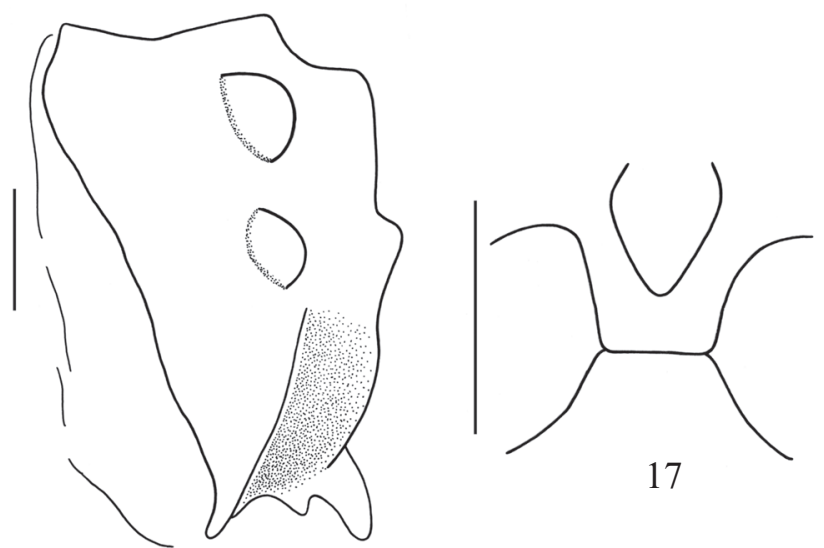

17

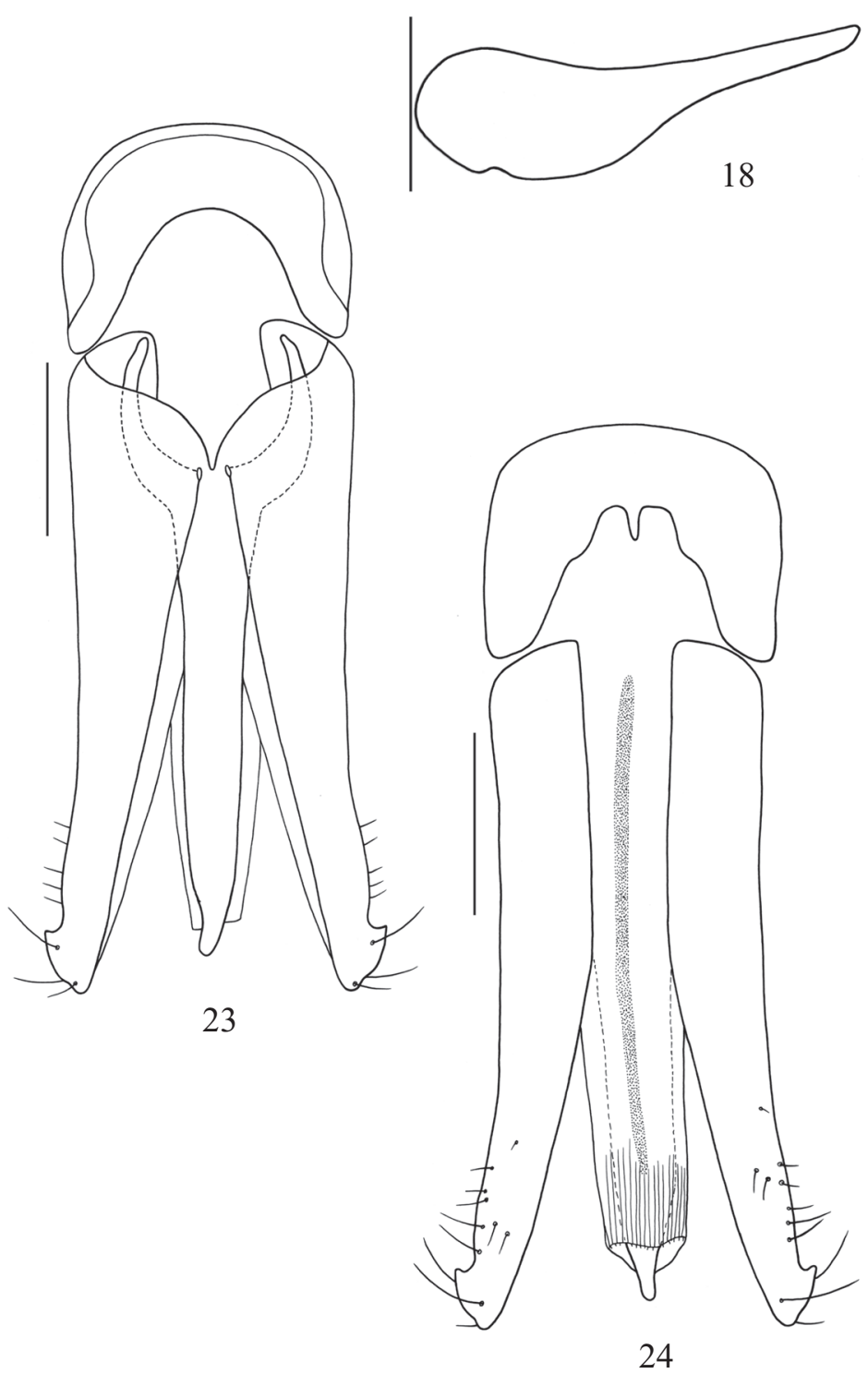

23
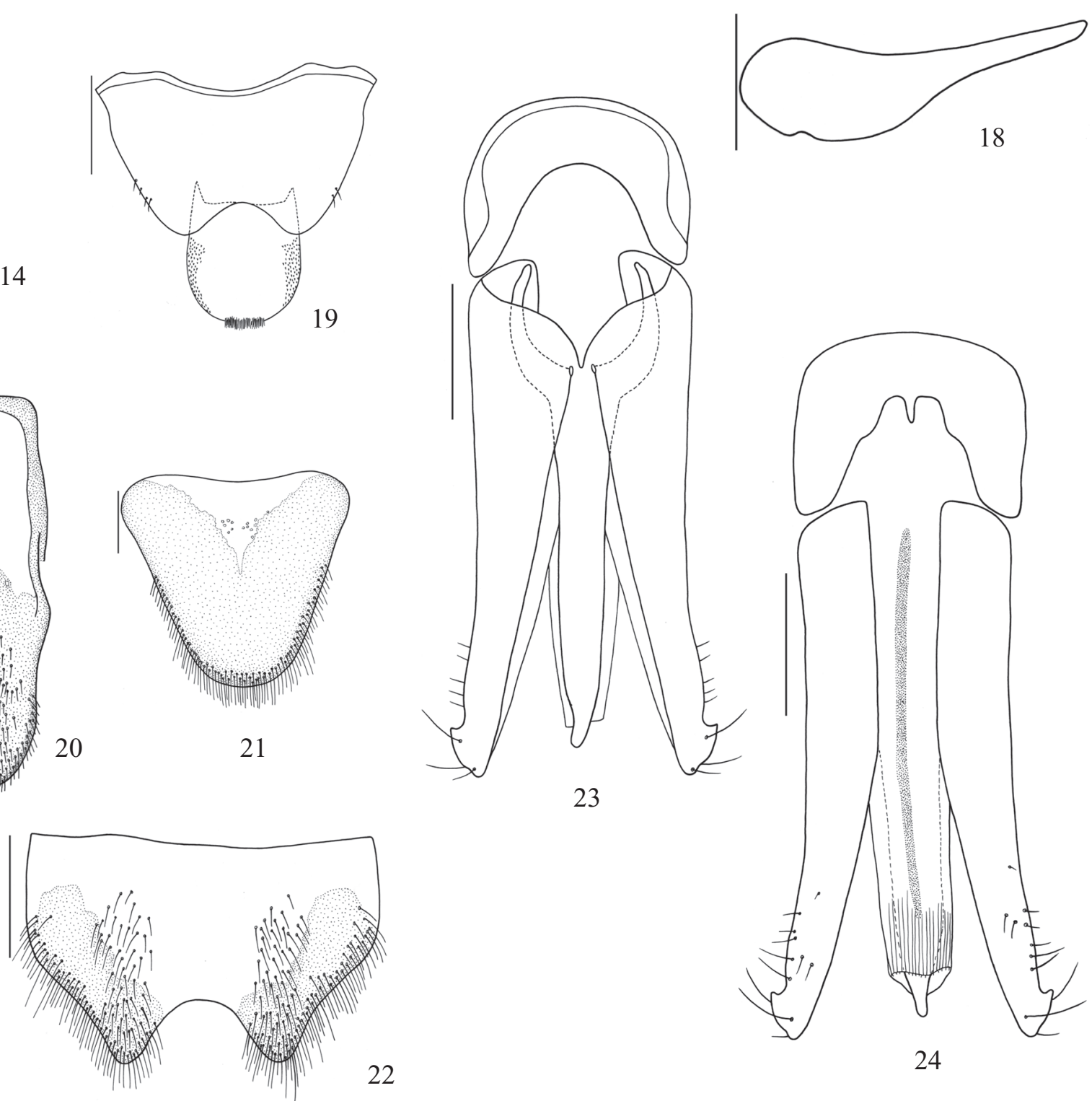

Figs. 14-24. Dilobitarsus bellus sp. nov. Male: 14, antenna; 15, frons and pronotum; 16, prothorax (lateral); 17, basal region of mesosternal cavity and median anterior region of metasternum; 18, metacoxal plate; 19, tergites IX-X; 20 sternite IX; 21, tergite VIII; 22, sternite VIII; 23, 24 aedeagus (dorsal, ventral). Bars $=5 \mathrm{~mm}$, except Figs. $14-18=1 \mathrm{~mm}$. 


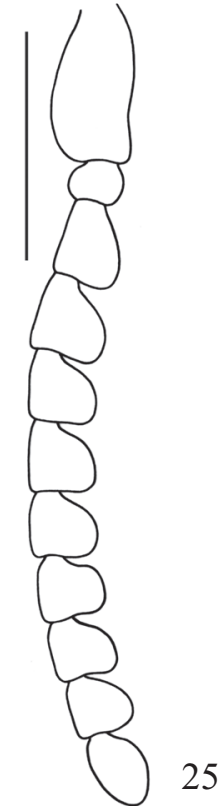

25

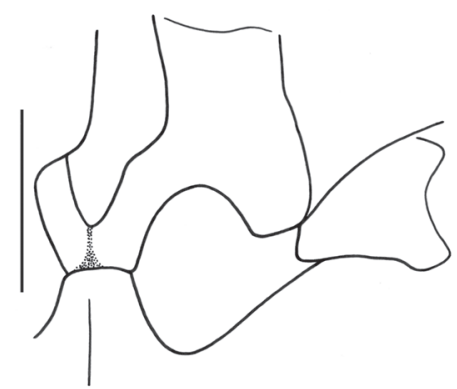

29

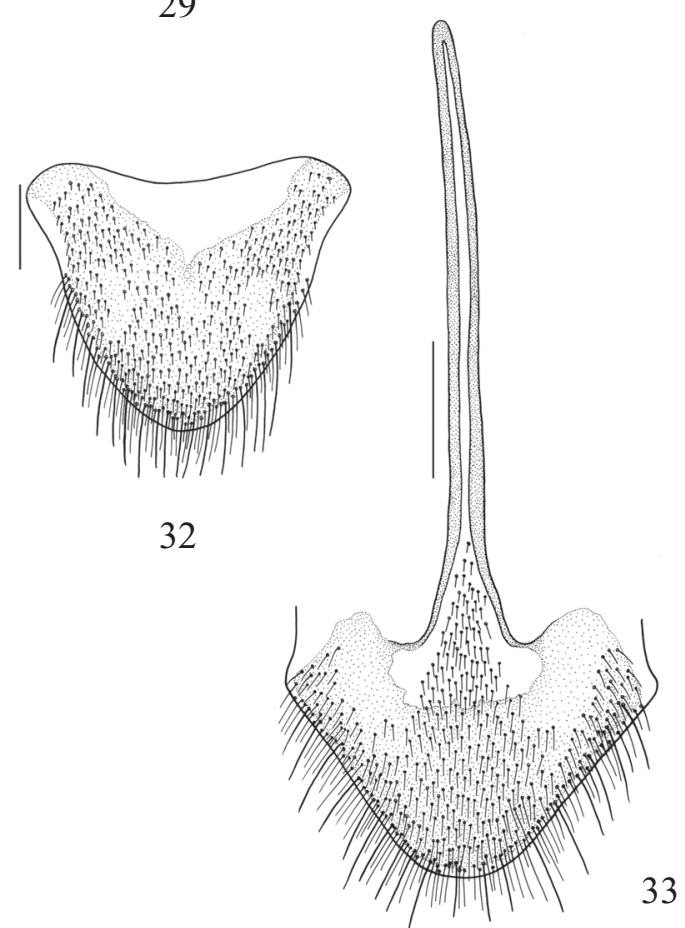

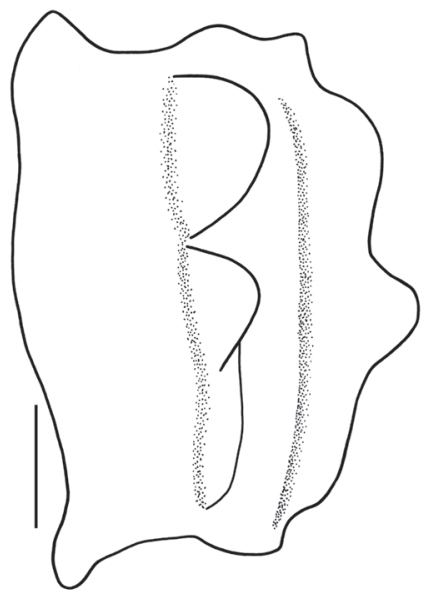

27
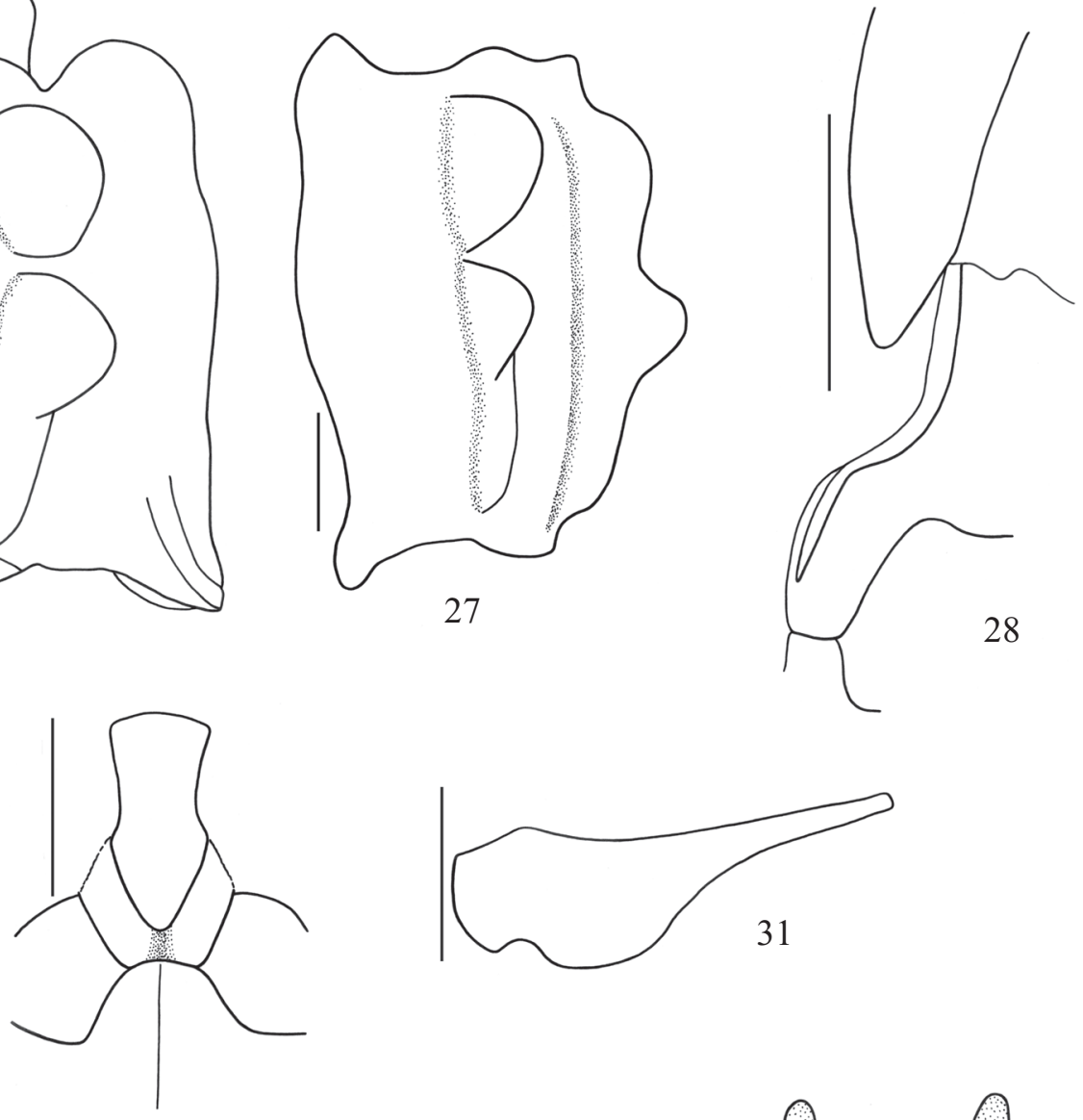

30
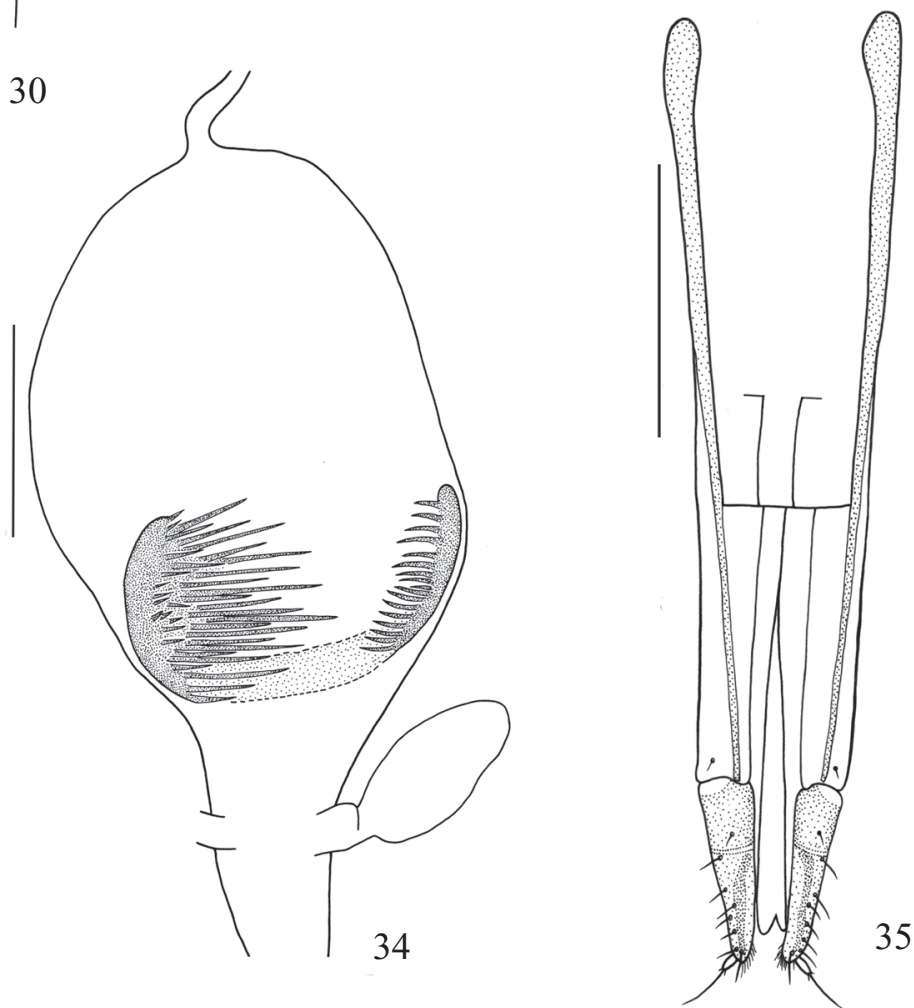

Figs. 25-35. Dilobitarsus nigrus sp. nov. Female: 25, antenna; 26, frons and pronotum; 27, prothorax (lateral); 28, prosternal spine and mesosternal cavity (lateral); 29, 30, mesosternal cavity and median region of metasternum (lateral, ventral); 31, metacoxal plate; 32, tergite VIII; 33, sternite VIII; 34, bursa copulatrix (ventral); 35, ovipositor and baculi (dorsal). Bars $=1 \mathrm{~mm}$, except Figs. 32 , $33=5 \mathrm{~mm}$; Figs. 34 , $35=10 \mathrm{~mm}$. 
grooved longitudinally medially forming one longitudinal elevation on each side of groove; two well-developed tubercles on each elevation: one anterior rounded and short and other basal, rounded and elongate, joined to longitudinal weak elevation; posterior pair of tubercles slightly larger than anterior; well-developed median basal tubercle at base of median groove; punctation coarse and dense. Hypomera with lateral margin sinuous; concave; grooved longitudinally, parallel pronotosternal groove; pronotosternal grooves slightly raised; smooth and strongly grooved near posterior margin (to accommodate profemur); punctation coarse and dense, coarser near antennal groove. Pronotosternal groove almost reaching procoxal cavity. Prosternum strongly convex, flattened between procoxae; punctation very coarse and dense, coarser than in hypomera. Prosternal lobe prominent and rounded, grooved transversally at base; anterior margin emarginate at middle, downwardly directed; punctation coarse and dense. Prosternal spine (Fig. 28) with apex acute, without subapical lobe. Mesepisternum and metasternum concave (to accommodate mesofemur). Mesosternal cavity (Figs. 28-30) with borders V-shaped, wide and horizontal on basal half and slightly declivous on anterior half. Metasternum wide and flat between mesocoxae, wider than base of mesosternal cavity, with punctation very coarse and dense; metathoracic discrimen well-marked. Metacoxal plate (Fig. 31) with wide rounded lobe and strongly narrowed on lateral half. Tarsomeres $2-4$ with very small lamella beneath. Claws with one long basal seta, slightly shorter than claw. Scutellum declivous, elongate with posterior margin rounded and anterior margin notched at middle.

Elytra (Figs. 79, 80) parallel, narrowed on distal fourth; convex, moderately declivous anteriad on anterior fifth; conjointly flattened dorsally on anterior two-thirds; striae weak, almost indistinct; coarse- and densely punctate; each elytrum with one small ridge on anterior half of interstice 4; apices narrow and conjointly rounded.

Tergite VIII (Fig. 32) wider than long, narrowed apicad, translucent at base; densely setose; setae longer near margins. Sternite VIII (Fig. 33) slightly wider than long (considering only sclerotized area), widened at basal fourth, narrowed on distal three-quarters; setae denser on longitudinal median band and longer near margins; spiculum gastrale 2.2 times longer than sternite. Ovipositor (Fig. 35) with one-segmented stylus with one long seta and some microsetae at apex. Bursa copulatrix with band-like sclerotized piece, with long teeth and microspined at base; sclerotized toothed band moderately short, reaching about one third of bursa copulatrix length.

Type material. Holotype female. Argentina. El Maiten Chubut, I.10.1965, A. Kovacs (AMNH).

Etymology. The specific epithet is a derivative of the Latin word nigrus (= black) referring to the colour of the integument.

Remarks. Dilobitarsus nigrus sp. nov. is easily recognized for its wide body and integument black, dense- and coarsely punctate; lateral margins of prothorax and elytra almost straight until distal third of elytra; pronotum with posterior pair of tubercles joined to longitudinal elevation and fore angles wide and rounded.

\section{Dilobitarsus thoraconstrictus sp. nov.}

(Figs. 36-47, 81, 82)

Description. Body length: $20 \mathrm{~mm}$. Integument reddishbrown; antennae and distal third of elytra black. Pubescence: golden-yellow on frons and pronotum, paler on basal half of pronotum; elytra with yellowish pubescence on reddishbrown integument and pubescence dark-brown on black integument; whole elytra with patches of yellowish setae; ventrally with yellowish-white setae; legs with yellowish setae (Figs. 81, 82).

Frons (Figs. 37, 81, 82) wider at base; fore angles prominent, rounded and slightly raised; strongly concave between fore angles; anterior margin straight and surpassing fore angles; concavity cordiform and strongly declivous; punctation coarse and dense. Antenna (Fig. 36) much longer than pronotosternal groove; serrate; $3^{\text {rd }}$ antennomere triangularelongate, as long as $4^{\text {th }}$.

Pronotum (Figs. 37, 38, 81, 82) longer than wide, strongly narrower than base of elytra (including hind angles); lateral margins slightly sinuous, narrowed at base of hind angles; fore angles prominent, narrowed and rounded; anterior margin rounded, slightly raised on median two-quarters; strongly convex on anterior half; slightly grooved near lateral margins; declivous and grooved at middle on posterior half; two pairs of rounded tubercles on anterior half, well separate, locate at extremities of an elevation, platform-like grooved at middle; basal pair of tubercles larger, almost twice longer than anterior; hind angles wide, triangular and not carinate; punctation coarse and dense; median basal tubercle wide and moderately developed. Hypomera concave; raised at border of pronotosternal groove; grooved longitudinally medially, parallel pronotosternal groove; smooth and strongly grooved near posterior margin (to accommodate profemur); punctation coarse and dense. Pronotosternal groove almost reaching procoxal cavity. Prosternum convex; punctation coarse and sparse, denser near prosternal lobe. Prosternal lobe prominent and rounded; distal margin slightly emarginate and downwardly directed; punctation very coarse (coarser than prosternum) and sparse. Prosternal spine (Fig. 39) with apex rounded and subapical lobe rounded. Mesosternal cavity (Figs. 39, 40) wide, V-shaped, horizontal on basal half and moderately declivous on anterior half. Mesepisternum carinate laterally at side of mesepimeron. Mesepimeron and anterior region of metasternum concave (to accomodate mesofemur). Metasternum wide and flat between mesocoxae, wider than base of mesosternal cavity; punctation coarse and dense, sparser medially; metathoracic discrimen weakly marked. Metacoxal plate (Fig. 41) with short and wide lobe, almost straight and strongly narrow at lateral half. Apex of tibia with row of spiniform setae. Tarsomeres 1-4 lamellate beneath; lamellae increasing in size from 1 to 4 ; lamella of 


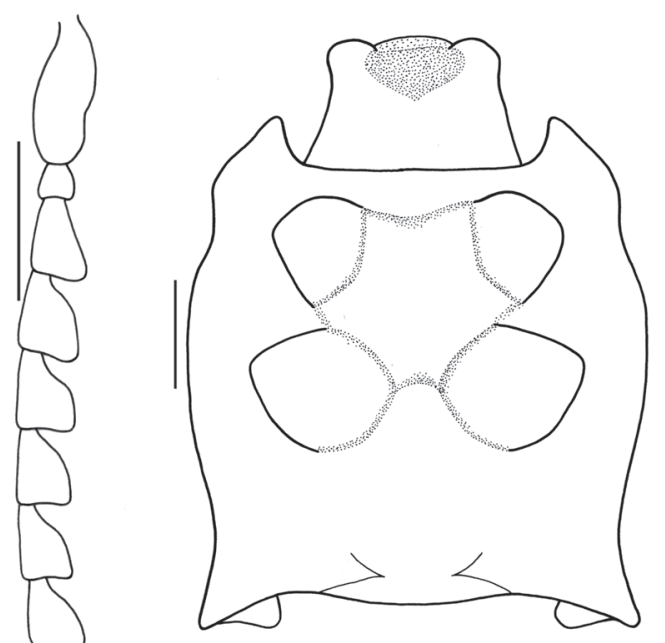

37

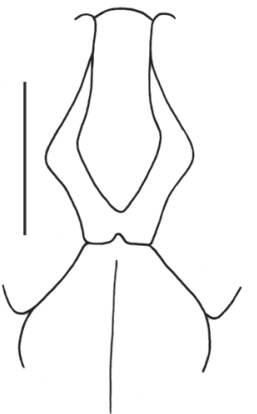

40
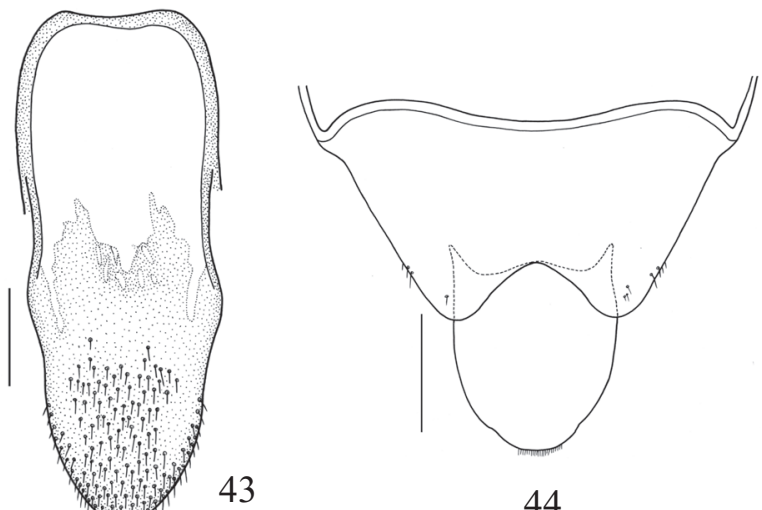

43
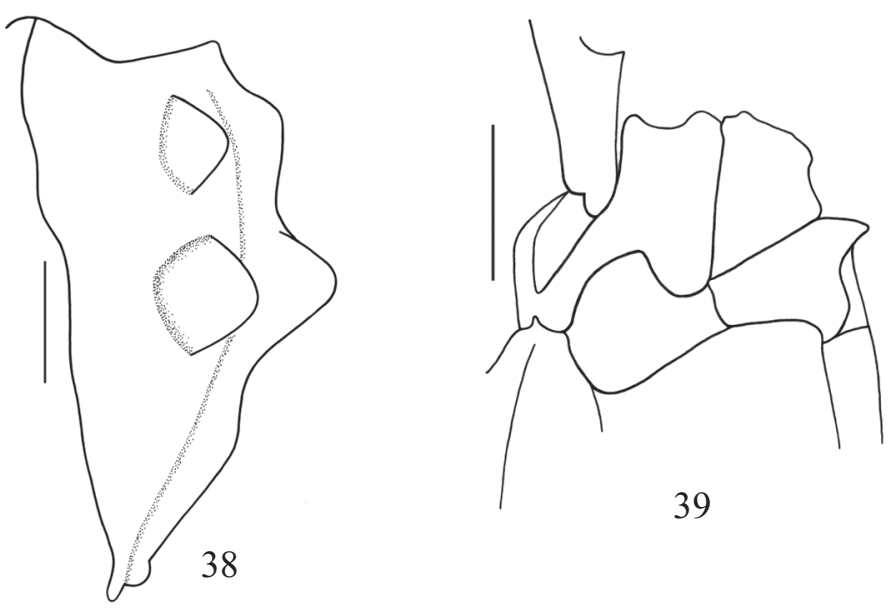

39

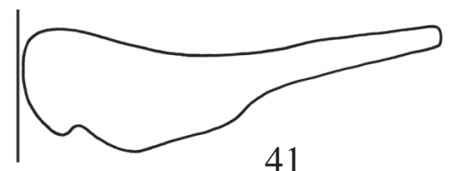

41

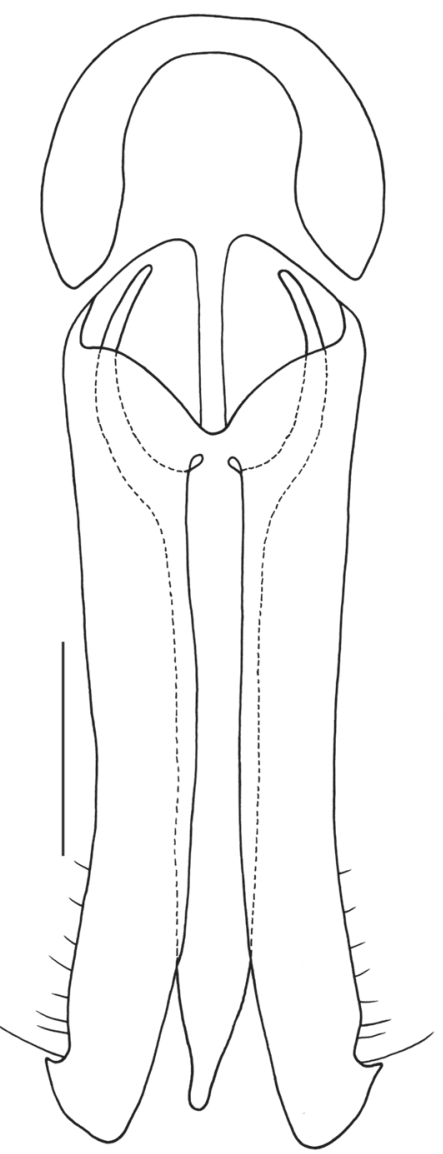

46

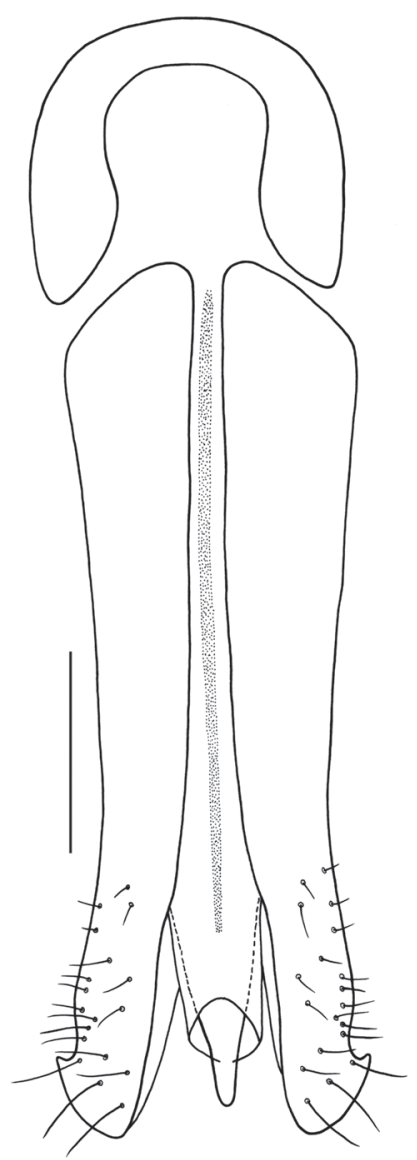

47

Figs. 36-47. Dilobitarsus thoraconstrictus sp. nov. Male: 36, antenna; 37, frons and pronotum; 38, prothorax (lateral); 39, prosternal spine, mesosternum and anterior region of metasternum (lateral); 40, mesosternal cavity and median anterior region of metasternum; 41, metacoxal plate; 42, tergite VIII; 43, sternite IX; 44, tergites IX-X; 45, sternite VIII; 46, 47, aedeagus (dorsal, ventral). Bars $=1 \mathrm{~mm}$, except Figs. $42-47=5 \mathrm{~mm}$. 
tarsomere 4 longer than tarsomere. Claws with one long basal seta; seta almost as long as claw. Scutellum elongate, pentagonal and declivous.

Elytra (Figs. 81, 82): distal half gradually narrowed apicad; strongly convex; basal region near scutellum strongly declivous anteriad; striae marked by rows of coarse translucent punctures on anterior two-thirds where integument is ferruginous; striae almost indistinct on distal third (black integument), where elytra are coarsely punctate; interstices flat, sparsely punctate; apices narrow and conjointly rounded; each elytron at base with one concavity near scutellum and other near lateral margin, forming a rounded tubercle between concavities and one elongate tubercle near fore angle.

Tergite VIII (Fig. 42) slightly longer than wide, slightly narrowed apicad; small triangular basal translucent area; covered by short setae (not represented in Fig. 42) and with long setae near margins. Sternite VIII (Fig. 45) transverse, bandlike, narrowed on distal half; anterior margin wide- and deeply emarginate forming two rounded lobes; translucent except for one irregular elongate band on each side; setae moderately long near lateral margins and on one longitudinal band starting on anterior lobe and not reaching base. Tergite IX (Fig. 44) transverse, gradually narrowed apicad; anterior margin widely emarginate; emargination slightly over onequarter of tergite length; few short setae near fore angles. Tergite X elongate, narrowed near apex. Sternite IX (Fig. 43) elongate, widened near middle, narrowed on distal fourth; apex narrowed and rounded; setae on distal third. Aedeagus (Figs. 46, 47): parameres separate ventrally, 1.4 times longer than median lobe (excluding basal struts); slightly wider and divergent on distal fourth; apex wide and unciform; setae dorsally on distal fourth; median lobe narrowed on distal fourth; basal struts surpassing basal margin of parameres dorsally and almost reaching base ventrally.

Type material. Holotype male. Bolivia. Santa Cruz, Rd to Amboro above Achira 27-28 oct 2011 Wappes \& Skillman; Rd to Floripondo $18^{\circ} 9^{\prime} \mathrm{S}$ $63^{\circ} 47^{\prime} \mathrm{W} 1900$ meters (MNKM).

Etymology. The specific epithet is a derivative of the Latin words thoracus (thorax) + constrictus (compressed) referring to the size of pronotum, narrower than elytra.

Remarks. This species is easily recognized by the prothorax narrower than elytral base and tubercles of pronotum long and widely rounded.

\section{Dilobitarsus quadrituberculatus Candèze, 1857}

$$
\text { (Figs. 48-72, 83-85) }
$$

Redescription. Body length: 11-18 mm. Integument reddish-brown; sometimes head and longitudinal median band on pronotum dark-brown. Pubescence yellowish-white and sparse; denser on pronotum, base of elytra and hypomera; brownish or dark-brown pubescence on fore angles of frons and longitudinal median band on pronotum; sometimes brownish pubescence on pronotum intermingled with yel- lowish setae giving an appearance of unicolor pronotum; each elytron with pubescence brownish or dark-brown in three irregular inclined patches, joined at base in an irregular longitudinal band parallel to lateral margin (Figs. 83-85).

Frons (Figs. 49, 83-85): basal half slightly declivous, slightly concave in a median triangular area; distal area concave and strongly declivous, almost perpendicular; anterior margin narrow, straight, carinate at labral level; fore angles raised; punctation coarse and dense. Antenna (Fig. 48) not reaching hind angles of pronotum, longer than pronotosternal groove (one antennomere longer in female and two in male); serrate with 11 antennomeres; laterodistal angle of antennomeres III-X slightly rounded; $3^{\text {rd }}$ antennomere narrower and as long as $4^{\text {th }}$. Labrum (Fig. 56) transverse, semielliptical with long setae on distal two-thirds. Epipharynx (Fig. 55) densely covered with thin setae; campaniform sensilla at median basal region. Mandibles (Figs. 57, 58) symmetrical with two distal teeth; penicillum well developed, formed by dense fringe of thin setae; longitudinal sinuous dorsal carina and long setae laterally, outside of carina. Maxilla (Fig. 60): cardo constricted at basal third with setae moderately long laterally near base; basistipes almost quadrangular with long setae of varied sizes; mediostipes rectangular with four setae moderately long near internal margin and microsetae (represented by punctures) distributed at external half; galea and lacinia brush-like; palpus densely setose; distal palpomere securiform. Labium (Fig. 59): mentum transverse, trapezoidal with long setae of varied sizes on basal two-thirds; prementum wide, transverse, marginate anteriorly by fine setae and a row of setae (interrupted at middle) parallel to distal margin; palpiger with three moderate long setae; distal palpomere very widened apicad.

Pronotum (Figs. 49, 50, 83, 84) longer than wide; fore angles flat and widely rounded; lateral margins almost straight; hind angles very wide, slightly divergent, not carinate; strongly convex, coarse and densely punctate; slightly grooved longitudinal medially; one pair of tubercles on discal area and one pair, usually larger, anteriorly; posterior margin with transverse flattened tubercle. Hypomera (Fig. 53) flat, grooved transversely at base (to accommodate profemur); dense- and coarsely punctate. Pronotosternal groove almost reaching procoxal cavity. Prosternal lobe very prominent and rounded, dense and coarsely punctate. Prosternum convex; punctation coarser than that of hypomera; antennal groove long almost reaching procoxa. Prosternal spine (Fig. 53) flattened laterally, apex acute with subapical lobe. Mesosternal cavity (Figs. 52, 53) V-shaped with borders narrow and slightly declivous on basal half and strongly declivous on distal half. Mesepisternum carinate laterally at side of mesepimeron. Mesepimeron and anterior region of metasternum grooved (to accomodate mesofemur). Metacoxal plate (Fig. 51) with wide and slightly rounded lobe; strongly narrowed on lateral half. Metasternum and ventrites densely and coarsely punctate; metathoracic discrimen well-marked. Scutelum elongate, narrowed at middle with anterior margin straight and posterior margin rounded. Tarsomeres 2-4 lamel- 


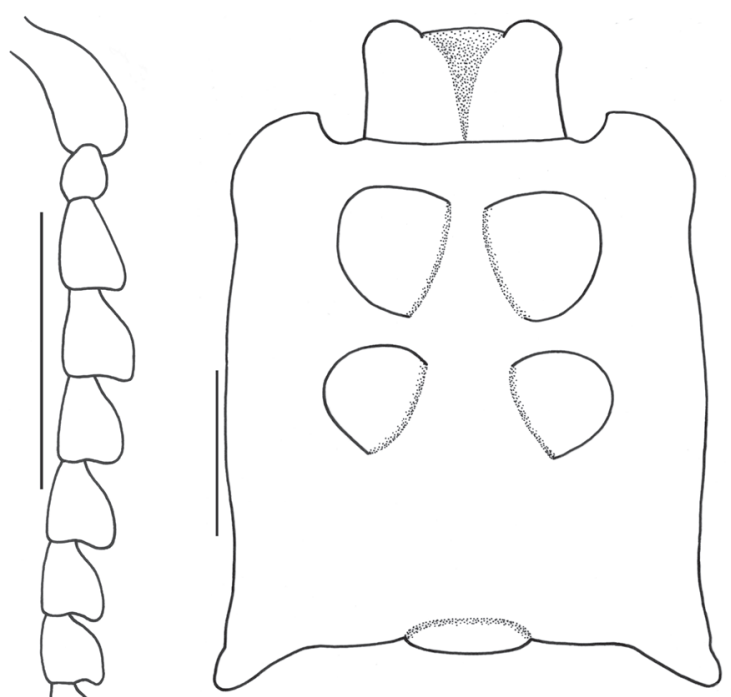

49

48

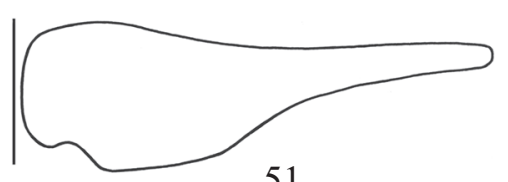

51

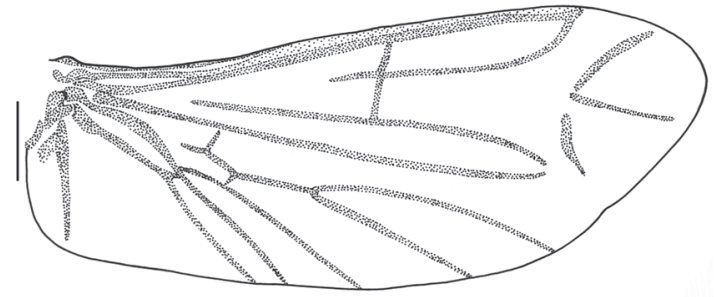

54
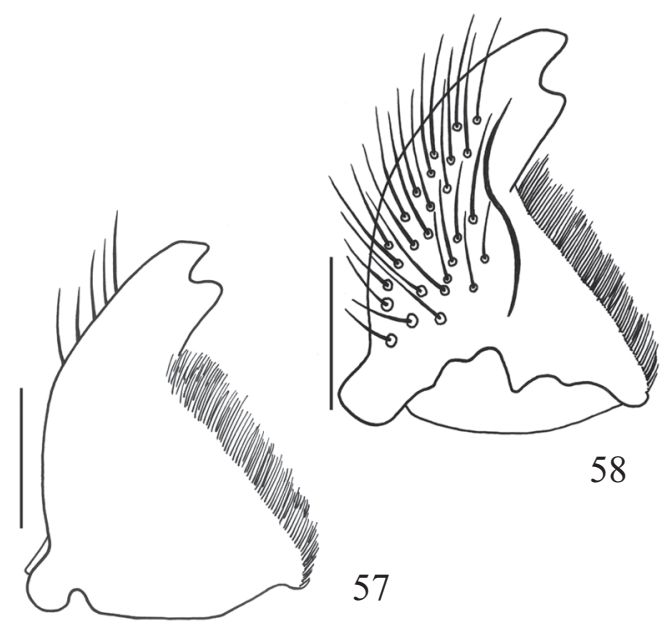

58

57

Figs. 48-60. Dilobitarsus quadrituberculatus Candèze, 1857. Male: 48, antenna; 49, frons and pronotum; 50, prothorax (lateral); 51, metacoxal plate; 52, mesosternal cavity and median anterior region of metasternum; 53, thorax (lateral); 54, hindwing; 55, epipharynx; 56, labrum; 57, 58, mandible (ventral, dorsal); 59, labium; 60, maxilla. Bars $=1 \mathrm{~mm}$, except Fig. $51=0.5 \mathrm{~mm}$; Figs. 57-60=2 mm.

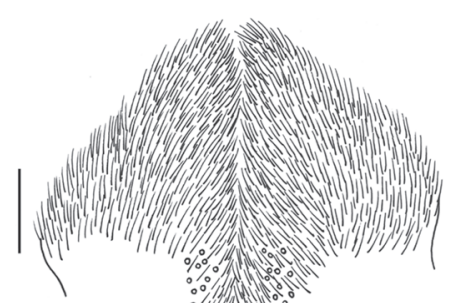

55

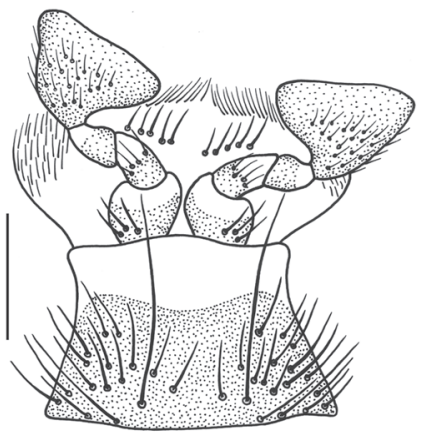

59

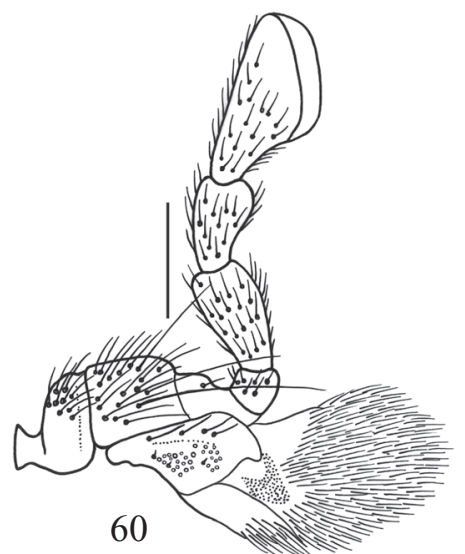

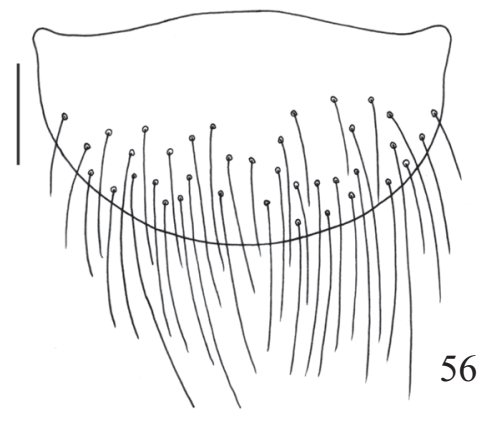

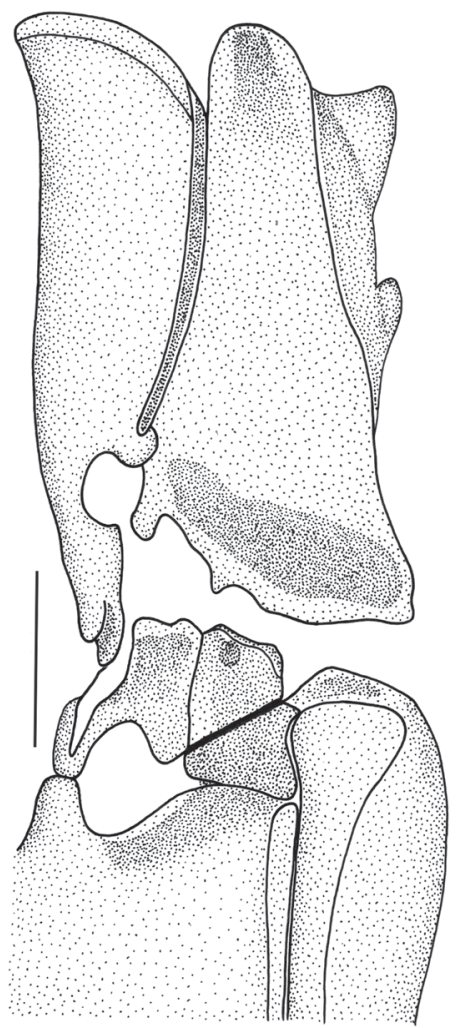

53

6 


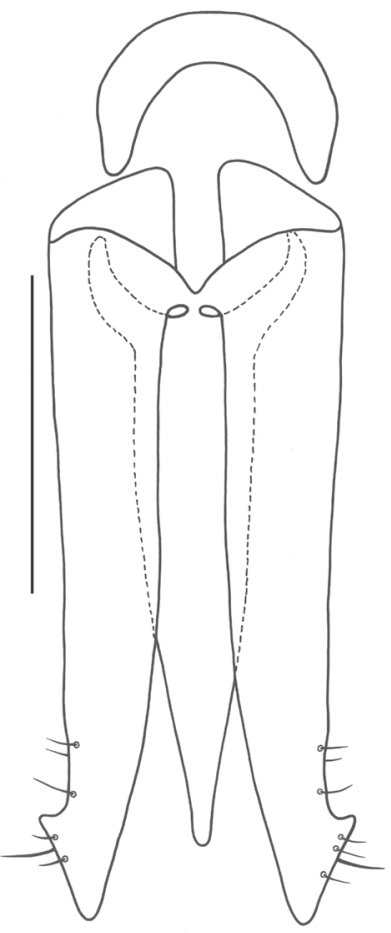

61
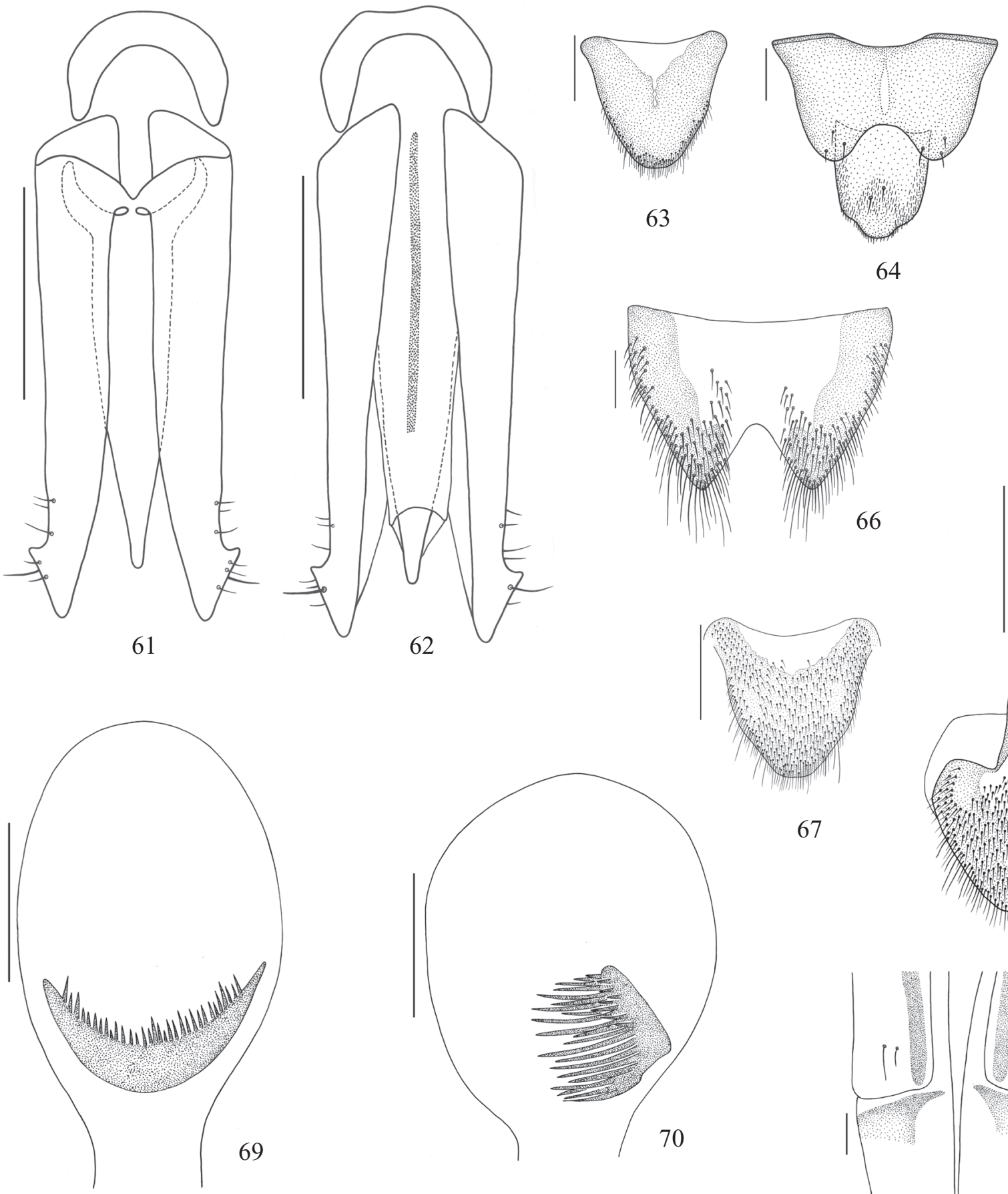

64

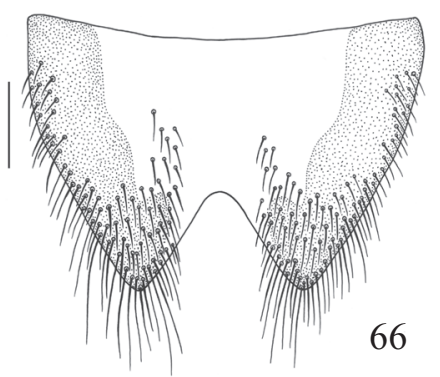

62
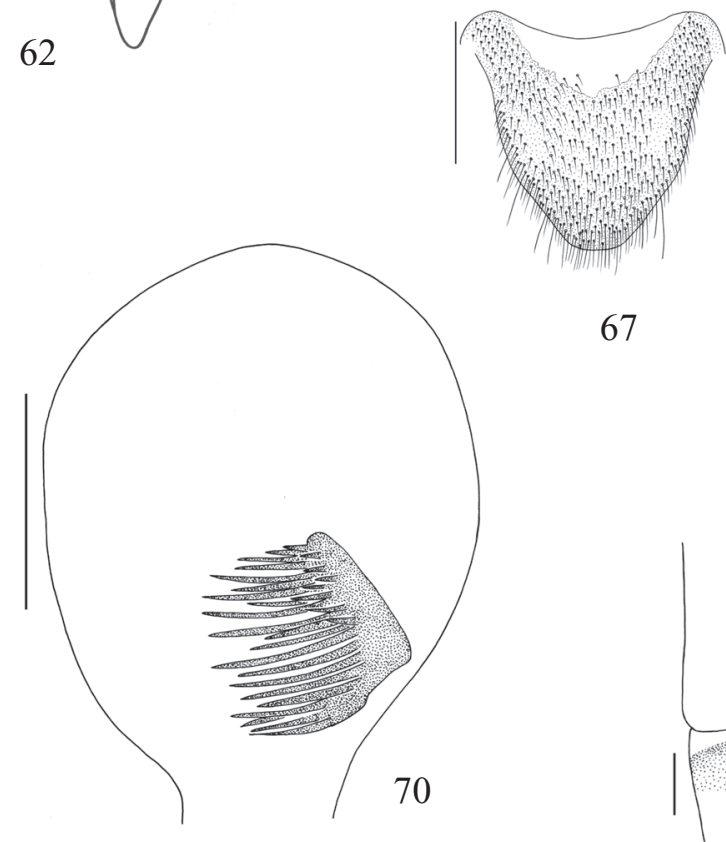

67

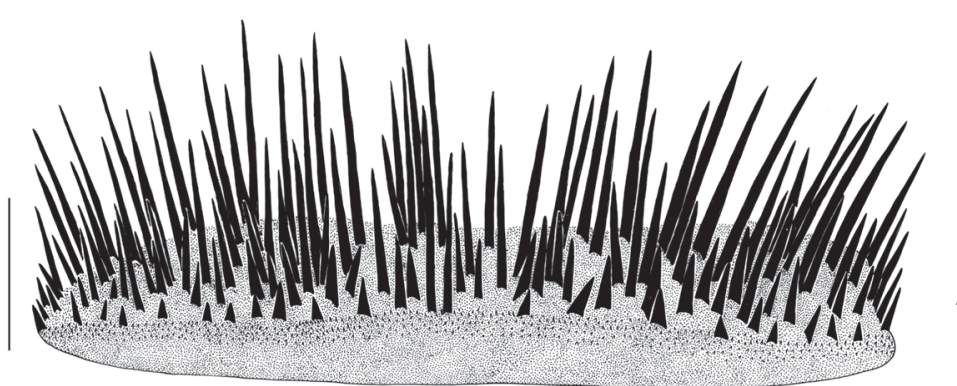

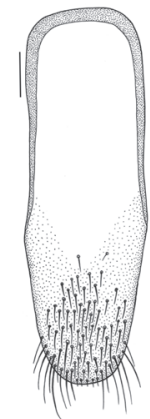

65

Figs. 61-72. Dilobitarsus quadrituberculatus Candèze, 1857. Male: 61, 62, aedeagus (dorsal, ventral); 63, tergite VIII; 64, tergites IX-X; 65, sternite IX; 66, sternite VIII. Female: 67, tergite VIII; 68, sternite VIII; 69, 70, bursa copulatrix (dorsal, lateral); 71, sclerotized piece of bursa copulatrix; 72, ovipositor. Bars $=5 \mathrm{~mm}$ except Fig. $72=1 \mathrm{~mm}$; Figs. 64, $66=2 \mathrm{~mm}$; Figs. $67-70=10 \mathrm{~mm}$. 

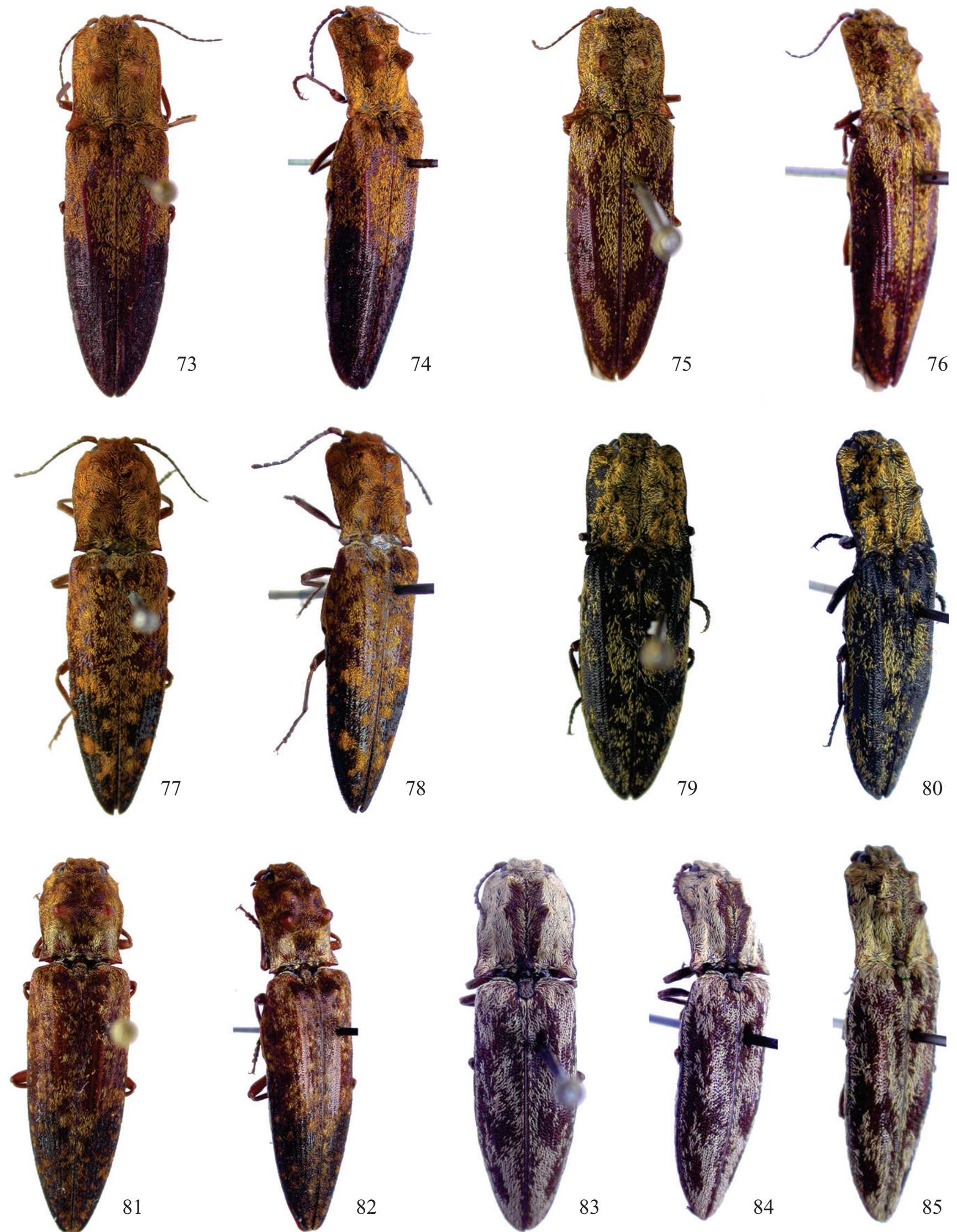

Figs. 73-85. Habitus (dorsal, laterodorsal). 73-76, Dilobitarsus angulosus sp. nov. (holotype, paratype); 77, 78, D. bellus sp. nov. (holotype); 79, 80, D. nigrus sp. nov. (holotype); 81, 82, D. thoraconstrictus sp. nov. (holotype); 83-85, D. quadrituberculatus. 
late beneath; lammelae of median size. Claws with one basal long seta; seta almost as long as claw.

Elytra (Figs. 83, 84) convex, gradually narrowed on distal half; conjointly flattened on anterior two-thirds; dense and coarsely punctate; apex narrow and conjointly rounded. Hind wing (Fig. 54): wedge cell opened; M4+Cu incomplete; three distal sclerites.

Male. Tergite VIII (Fig. 63) wider than long, slightly narrowed apicad; basal region translucent at middle; distal half marginate by short setae (not represented in Fig. 63); long setae near margins. Sternite VIII (Fig. 66) transverse, gradually narrowed apicad; distal margin deeply notched, V-shaped, forming two acute lobes; setae moderately long laterally and on distal angles. Tergite IX (Fig. 64) transverse, slightly narrowed apicad; lateral margins sinuous; distal margin widely emarginate forming two rounded lobes; emargination about onequarter of tergite length; a few short setae at lobes. Tergite IX elongate strongly narrowed at apex; short setae laterally and at middle; two longer setae at middle. Sternite IX (Fig. 65) elongate, slightly widened at middle; distal margin wide and rounded; setae moderately long on distal fourth, longer near angles. Aedeagus (Figs. 61, 62): parameres separate ventrally, 1.4 times longer than median lobe (excluding basal struts) with apex narrowed and cuneiform; subapical tooth wide and lateral inclined margin straight; median lobe moderately wide, gradually narrowed apicad; basal struts as long as parameres dorsally and not reaching parameres base ventrally.

Female. Tergite VIII (Fig. 67) wider than long, slightly narrowed apicad; translucent at base; densely setose; setae longer near margins. Sternite VIII (Fig. 68) wider than long (considering only sclerotized area) slightly narrowed on distal three-quarters; densely setose; setae longer near margins; spiculum gastrale 2.3 times longer than sternite. Ovipositor (Fig. 72) with one-segmented stylus with one long seta and several microsetae at apex; bursa copulatrix (Figs. 69, 70) with bandlike sclerotized piece, with long teeth and microspined near base (Fig. 71); sclerotized toothed piece short.

Examined material. BRAZIL. Minas Gerais: Poços de Caldas (Morro S. Domingos), 1 ex. (MZSP). Rio de Janeiro: Rio de Janeiro (Bom Retiro), 1 ex.(MNRJ). São Paulo: Barueri, 3 exs. (MZSP); Botucatu, 1 ex. (MZSP); Itu (Faz. Pau d'Alho), 1 ex. (MZSP); Rio Claro, 1 ex. (MZSP); São Carlos, 1 ex. (MZSP); São Paulo, 1 ex. (MZSP); (Ipiranga), 1 ex. (MZSP), (Jabaquara), 1 ex. (MZSP), (Poa), 1 ex. (MZSP). Paraná: Caviuna, 2 exs. (AMNH); Curitiba, 3 exs. (DZUP), 2 exs. (MZSP); Morretes (Vista Lacerda), 1 ex. (DZUP); Ponta Grossa (Lajeado), 2 exs. (DZUP); Rolandia, 3 exs. (AMNH), 1 ex. (MZSP). Santa Catarina: Corupa (Hansa Humboldti), 2 exs. (AMNH); Rio Vermelho, 2 exs. (MZSP). Rio Grande do Sul: Porto Alegre 2exs. (1 disssected) (MCNZ); São Jerônimo, 2 exs. (MZSP); Triunfo, 1 ex. (MCNZ). PERU. Junin: Satipo, Jauja Prov., 1 ex.(AMNH); Tarma Prov. (Utcuyacu), 1 ex. (AMNH)

Distribution. Originally this species was recorded from Minas Gerais and Santa Catarina, in Brazil. Mecke et al. (2001) recorded D. quadrituberculatus associated with Araucaria angustifolia (Bert.) (O. Kuntze) in Rio Grande do Sul (Brazil). Here, this species is recorded also from Peru and the Brazilian states of Rio de Janeiro, São Paulo and Paraná. One specimen from Humaitá (Amazonas, Brazil), deposited at MZSP, was not included because its identity needs confirmation.

Remarks. According to Candèze (1857), D. quadrituberculatus resembles $D$. lignarius, but the tubercles on the pronotum are larger and not sharpened at apex, and $D$. lignarius possesses very small tarsal lamellae. I examined a photograph of the type of $D$. lignarius from the Natural History Museum, London, and observed also differences on the coloration of dorsal pubescence: in D. lignarius the yellowish pubescence is paler and the brownish bands and patches on pronotum and elytra are almost indistinct; in $D$. quadrituberculatus the pubescence is yellowish-white, very denser on pronotum and basal region of elytra and the pronotum usually has darker pubescence on longitudinal median band and the elytron presents darker pubescence on three inclined patches and longitudinal lateral band.

\section{CONCLUSIONS}

Von Hayek (1973) presented the following generic diagnosis for Dilobitarsus: each tarsal claw with a group of setae at base $\left.{ }^{*}\right)$; tibial spurs absent; mesepisternum does not form part of the margin of the mesocoxal cavity; mesepimeron forms part of the margin of the mesocoxal cavity; third antennomere larger than second, similar to the fourth (*); antennal groove of variable depth, always extending beyond the anterior half of the pronotosternal suture; body clothed with narrow scales; prothorax not constricted behind the anterior angles, lateral carina present; pronotum with or without tubercles; hypomera and metasternum without welldefined grooves for the reception of the anterior and middle tarsi (*); scutellum simple, without carina; third and fourth tarsomeres with ventral lobes $\left(^{*}\right)$. Almost all these characters were observed in the studied species and were not included in the descriptions/redescription. However, the characters marked with an asterisk are presented in a different state compared to von Hayek's diagnosis and are here discussed.

The studied species, all with a tetra-tuberculated pronotum, possess claws with only one basal seta, third antennomere triangular-elongate and as long as $4^{\text {th }}$, except in D. bellus sp. nov. in which it is longer than $4^{\text {th }}$, and antennal groove as long as pronotosternal suture. The hypomera and metasternum do not exhibit well-defined grooves but weak concavities to accommodate the profemora. The tarsomeres $2-4$ are lamellate with lamellae of different sizes; usually the tarsomere 1 also possesses a small lamella, difficult to see in species with very small lamellae in the tarsomeres. In addition, it was observed that the majority of the studied species possess the prosternal spine with an acute or rounded apex and the subapical lobe rounded (Figs. 4, 39), except D. nigrus sp. nov.(Fig. 28) which has the apex of the prosternal spine without a subapical lobe.

Males of three species were studied: D. bellus sp. nov., $D$. quadrituberculatus and D. thoraconstrictus sp. nov. Comparing the male genitalia of these species it was observed that the genital segments are very similar in shape. The tergite VIII is wider than long in D. bellus sp. nov. and $D$. quadrituberculatus (Figs. 21, 63) and as long as wide in $D$. 
thoraconstrictus sp. nov. (Fig.42). The tergite IX (Figs. 19, 44,64 ) differs especially in the degree of emargination of its distal margin, weaker in $D$. bellus sp. nov.; in this species the tergite X (Fig. 19) is microspined laterally. The sternite VIII differs especially in the shape of the emargination of its distal margin, V-shaped and deep, almost reaching half of sternite length in D. quadrituberculatus (Fig. 66) and wide and rounded (U-shaped) in the remaining species, wider and shorter in D. thoraconstrictus sp. nov. (Fig. 45). The sternite IX differs especially at apex, narrower in $D$. thoraconstrictus sp. nov.(Fig. 43), and the sinuosity of the middle of lateral margins, stronger in D. bellus sp. nov. (Fig. 20) and almost straight in D. quadrituberculatus (Fig. 65). The aedeagum (Figs. 23, 24, 46, 47, 61, 62) has the parameres separate ventrally with a subapical lateral tooth, but the shape and size of this region is different in the three studied species.

Females of three species were studied: D. angulosus sp. nov., D. quadrituberculatus and D. nigrus sp. nov. Comparing these species it was observed that the tergites and sternites VIII are very similar in shape, differing especially on chaetotaxy, size of translucent basal area and relation between sternite VIII and spiculum gastrale, varying from 2.02.30 times longer than sternite. The ovipositor possesses apically one-segmented styli except for the holotype of $D$. angulosus sp. nov. In this specimen the stylus is lacking. Observing the apex of ovipositor, it does not seem to have been broken and, in addition, before being dissected, the ovipositor was totally introverted into the abdomen. The bursa copulatrix of all studied species present a band-like sclerotized piece with long teeth and one microspined basal band.

\section{Key to the species of Dilobitarsus from the Neotropical region (after Candèze (1857) and Golbach (1983))}

1. Pronotum with tubercles 2

1 '. Pronotum without tubercles. 19

2 (1). Six tubercles on pronotum $(18 \mathrm{~mm})$ (Colombia) ...... D. irroratus Candèze, 1857

2'. Less than six tubercles on pronotum .. 3

$3\left(2^{\prime}\right)$. Four tubercles on pronotum .. 4

3'. Two tubercles on pronotum 11

4(3). Tubercles weak; hind angles of pronotum wide, almost straight, quadrangular (11 mm) (Colombia, Argentina) .

D. colombianus Candèze, 1857

4'. Tubercles very or moderately raised, but always wellvisible; hind angles of pronotum variable .. 5

5(4'). Pronotum almost as long as wide (Fig. 26), slightly wider than base of elytra; fore angles of pronotum wide and rounded and lateral margins almost straight; integument entirely black (Figs. 79, 80) (16 mm) (Argentina) .............................................. D. nigrus sp. nov.

5'. Pronotum clearly longer than wide; width of pronotum and fore angles variable; lateral margins curved or sinuous in varying degrees. $6\left(5^{\prime}\right)$. Hind angles of pronotum almost straight, slightly divergent, not carinate (Fig. 49); fore angles of pronotum flat, wide and rounded; tubercles of pronotum very raised; darker pubescence usually forming longitudinal median band on pronotum (Figs. 83, 84) (11-18 mm) (Brazil: Minas Gerais, Rio de Janeiro, São Paulo, Paraná, Santa Catarina, Rio Grande do Sul; Peru).

D. quadrituberculatus Candèze, 1857

6 '. Hind angles of pronotum very divergent or only narrowed at base, carinate or not; fore angles of pronotum narrow and rounded; shape of tubercles and pubescence coloration variable

7(6'). Hind angles of pronotum very prominent (Fig. 2), wider than lateral margins of pronotum; pubescence of pronotum yellow; distal half of elytra with pubescence entirely darkbrown or dark-brown with golden yellow patches (Figs. 73-76) (18-23 mm) (Brazil: Rio de Janeiro, São Paulo). D. angulosus sp. nov.

7'. Hind angles of pronotum slightly prominent, slightly wider than lateral margins of pronotum; pubescence different ... 8

$8\left(7^{\prime}\right)$. Tubercles of pronotum strongly raised (Fig. 38) ..... 9 8 '. Tubercles of pronotum moderately raised 10

9 (8). Pronotum narrower than base of elytra; fore angles of pronotum narrowed (Fig. 37); distal third of elytra black (Figs. 81, 82) $(20 \mathrm{~mm})$ (Bolivia)

D. thoraconstrictus sp. nov.

9'. Pronotum slightly narrowed at base of hind angles (Fig. 15) and slightly narrower than base of elytra; pubescence of elytra predominantly golden-yellow, distal third black with patches of denser golden-yellow setae (Figs. 77, 78) $(18 \mathrm{~mm})($ Peru) D. bellus sp. nov.

$10\left(8^{\prime}\right)$. Pubescence of elytra predominantly silvery; punctation of elytra fine and sparse $(25 \mathrm{~mm})$ (Colombia) ........ D. cariosus Candèze, 1889

10'. Pubescence of elytra predominantly golden-yellow; punctation of elytra stout and very dense (11-18 mm) (Argentina, Brazil, Uruguay, Paraguay)

D. lignarius Candèze, 1857

11(3'). Two tubercles at middle of pronotum $(25 \mathrm{~mm})$ (Colombia) D. deyrollei Candèze, 1857

11'. Two tubercles at anterior half of pronotum .............. 12

12(11'). Pronotum visibly longer than wide, wider anteriorly

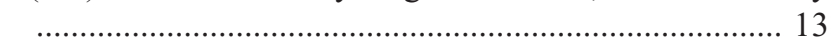

12'. Pronotum almost square, wider at middle ................ 16

13(12). Pronotum with longitudinal groove medially ..... 14 13 '. Pronotum without longitudinal groove medially ..... 15

14(13). Hind angles of pronotum shortened (17 mm) (Colombia) ...................................... D. nubilus Candèze, 1857

14'. Hind angles of pronotum entire and not reduced (14 $\mathrm{mm}$ ) (Mexico, Nicaragua, Panama)

D. eloini Candèze, 1874 
15(13'). Pronotum strongly sinuous when seen laterally (Mexico, Guatemala, Nicaragua) (18 mm)

D. inopinus Candèze, 1874

$15^{\prime}$. Pronotum slightly sinuous when seen laterally (1516 mm) (Central America, Venezuela, Colombia, Peru, Brazil, Bolivia, Paraguay, Argentina) ....

D. bidens (Fabricius, 1801)

$16\left(12^{\prime}\right)$. Two longitudinal ridges on elytra (14 mm) (Brazil: Rio de Janeiro) D. bicornis Candèze, 1857

16'. Elytra without ridges 17

$17\left(16^{\prime}\right)$. Pronotum without longitudinal median groove (12 $\mathrm{mm}$ ) (Bolivia) D. corrosus Candèze, 1897

17'. Pronotum at least at posterior half with a groove .... 18

18(17'). Two well-visible tubercles on pronotum; posterior half of pronotum widely flattened; elytra without grooves (Peru). D. impressicollis Schwarz, 1902

18'. Two inconspicuous tubercles on pronotum; pronotum grooved along entire length; elytra weakly grooved (13 $\mathrm{mm})$ (Ecuador) ................. D. subsulcatus Candèze, 1874

$19\left(1^{\prime}\right)$. Antennal groove as long as or longer than antenna.

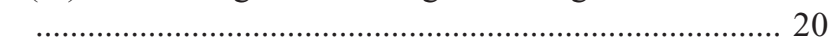

19'. Antennae visibly longer than antennal grooves ....... 25

20(19). Pronotum more than twice as long as wide (12 mm) (Brazil: Amazonas, Pará; Peru) ..... D. gracilis Candèze, 1874 20 '. Pronotum transverse or slightly longer than wide ... 21

$21\left(20^{\prime}\right)$. Hind angles of pronotum carinate 22

21 '. Hind angles of pronotum not carinate 24

22(21). Base of elytra and external region of humerus grooved longitudinally (15 mm) (French Guiana) D. nebulosus Candèze, 1874

22'. Base of elytra without grooves 23

23(22'). Carina of hind angles of pronotum strong and parallel to external margin (12 mm) (Brazil, Venezuela).

D. petiginosus Germar, 1840

23'. Carina of hind angles of pronotum weak and not parallel to external margin (Paraguay)

D. carumbeus Golbach, 1983

24(21'). Pronotum clearly transverse (9 mm) (Brazil) ........ D. abbreviatus Candèze, 1857

24'. Pronotum square (13 mm) (Brazil: Rio de Janeiro) .....

D. tesselatus Candèze, 1874

25(19'). Pronotum grooved medially along entire length (Chile, Argentina) ............... D. sulcicollis (Solier, 1851)

$25^{\prime}$. Pronotum not grooved or grooved only along posterior half 26

$26\left(25^{\prime}\right)$. Pronotum without groove (Chile, Argentina) ........ .. D. vitticolis (Fairmaire \& Germain, 1860)

26'. Pronotum grooved along posterior half. 27

27(26'). Pronotum wider at middle; pubescence of elytra black, white and brownish; black setae forming wide patch at posterior half of each elytron (Chile, Argentina) ........ D. laconoides (Fleutiaux, 1907)

27'. Pronotum wider posteriorly; pubescence of elytra uniformly black (Chile) D. crux (Philippi, 1860)

\section{ACKNOWLEDGEMENTS}

To James Wappes (ACMT) for sending the material for identification; L. Herman (AMNH), M.H.M Galileo (MCNZ), L. Massutti (DZUP) and M. Monné (MNRJ), curators of the Coleoptera collections, for lending the studied material; Dr. C. Costa (MZSP) for bringing the studied material as loan (except ACMT); Max Barclay and Alex Greenslade from Natural History Museum, London, for taking the photographs of the types of $D$. colombianus Candèze and $D$. lignarius Candèze; two anonymous reviewers for comments and suggestions.

\section{REFERENCES}

Candèze, E. 1857. Monographie des Élatérides vol. I. Mémoires de la Société Royale des Sciences de Liège 12: 1-400.

Candèze, E. 1874. Révision de la monographie des Élatérides. Mémoires de la Société Royale des Sciences de Liège 4 (ser. 2): 1-218.

Candèze, E. 1889. Élatérides Nouveaux 4. Annales de la Societé Entomologique de Belgique 33: 67-123.

Candèze, E. 1897. Élatérides Nouveaux 6. Mémoires de la Société Royale des Sciences de Liège 29:1-88.

Fabricius, J.C. 1801. Systema eleutheratorium. 1, xxiv+506 p 2, 687p, Kiel. Fairmaire, L. \& Germain, P. 1860. Coleoptera Chilensia. Revue et Magasin de Zoologie 12: 267-269.

Fleutiaux, E. 1907. Révision des Élatérides du Chili. Revista Chilena de Historia Natural 11: 160-232.

Fleutiaux, E. 1934. Descriptions d'Élatérides nouveaux. Bulletin de la Société Entomologique de France 39:178-185.

Germar, E.F. 1840. Bemerkungen über Elateriden. Zeitschrift für Entomologie 2: 241-279.

Golbach, R. 1983. Contribucion al conocimiento de la subfamilia Agrypninae de Sudamérica con descripción de 3 especies nuevas (Col. Elat.). Acta Zoologica Lilloana 37: 141-152.

Latreille, P.A. 1834. Distribution méthodique et naturelle des genres de diverses tribus d'insectes Coléoptères de la famille des Serricornes. Annales de la Societé Entomologique de France 3: 113-170.

Mecke, R., Galileo, M.H.M. \& Engels, W. 2001. New records of insects associated with Araucaria trees: Phytophagus Coleoptera and Hymenoptera and their natural enemies. Studies on Neotropical Fauna and Environment 36: 113-124.

Philipi, R.A. \& Philippi, A.H.E. 1860. Coleoptera nonnulla nova Chilensia praesertim Valdiviana. Entomologische Zeitung 21: 245-251.

Schwarz, O. 1902. Neue Elateriden aüs Südamerika, besonders aus Peru. Deutsche Entomologische Zeitschrift 1902: 129-152.

Solier, A.J.J. 1851.Coleópteros elaterídeos, p.5-38. In: Gay, C., editor. Historia fisica y politica de Chile. Zoologia vol. 5. Paris \& Santiago, 563 p.

Von Hayek, C.M.F. 1973. A reclassification of the subfamily Agrypninae (Coleoptera: Elateridae). Bulletin of the British Museum (Natural History) Entomology (suppl 20): 1-309.

Received 5 June 2013; accepted 21 August 2013

Associate Editor: Marcela L. Monné 